\title{
REIT Capital Structure Choices: Preparation Matters
}

\author{
Andrey Pavlov*A, Eva Steiner ${ }^{\mathrm{B}}$ and Susan Wachter ${ }^{\mathrm{C}}$

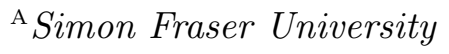 \\ ${ }^{\mathrm{B}}$ University of Cambridge \\ ${ }^{\mathrm{C}}$ University of Pennsylvania
}

\begin{abstract}
Sun, Titman, and Twite (2015) find that capital structure risks, namely high leverage and a high share of short-term debt, reduced the cumulative total return of US REITs in the 2007-2009 financial crisis. We find that mitigating capital structure risks ahead of the crisis by reducing leverage and extending debt maturity in 2006, was associated with a significantly higher cumulative total return 2007-2009, after controlling for the levels of those variables at the start of the financial crisis. We further identify two systematic cross-sectional differences between those REITs that reduced capital structure risks prior to the financial crisis and those that did not: the exposure to capital structure risks and the strength of corporate governance. On balance, our findings are consistent with the interpretation of risk-reducing adjustments to capital structure ahead of the crisis as a component of managerial skill and discipline with significant implications for firm value during the crisis.
\end{abstract}

Key words: Real estate investment; leverage; financial crisis

* Corresponding author: Beedie School of Business, Simon Fraser University, Vancouver, Canada, 6047787922 (Phone), 6042914920 (Fax), apavlov@sfu.ca (Email). We thank seminar participants at the NAREIT Conference 2015 and two anonymous referees for their helpful comments and suggestions. Andrey Pavlov acknowledges financial support from the Social Science and Humanities Research Council of Canada. Eva Steiner acknowledges support from the Cambridge Endowment for Research in Finance. Susan Wachter acknowledges financial support from the Zell Lurie Real Estate Center at the Wharton School of the University of Pennsylvania. 


\section{Introduction}

REIT managers are able to mitigate capital structure risk in two fundamental ways: They can always be conservative, or they can dynamically adjust capital structure in anticipation of future market conditions. Sun, Titman, and Twite (2015) find that firms with a conservative capital structure at the start of the 2007-2009 financial crisis performed better during the financial crisis. On the other hand, their findings suggest that risky capital structure characteristics, such as high leverage and a high share of short-term debt, significantly reduced the cumulative total return of US REITs over the 2007-2009 financial crisis period.

We extend this study by documenting that REITs that dynamically adjusted their capital structure prior to the financial crisis performed better during the financial crisis, after controlling for their capital structure characteristics at the start of 2007. Our finding thus suggests that shareholders rewarded REIT managers who correctly identified the risk of a financial crisis and took actions to prepare for it by mitigating capital structure risks. Our result implies that, in addition to selecting profitable investments and managing them effectively, REIT managers are able to improve firm value through dynamic financing choices in anticipation of future risks. In economic terms, our estimates suggest that a one standard deviation reduction in leverage before the financial crisis generated a 5\% higher cumulative return 2007-2009.

In order to distinguish between deliberate and lucky changes in capital structure, we further identify two systematic cross-sectional differences among those REITs that made adjustments to their capital structure ahead of the financial crisis and those that did not. We find that US REITs with higher capital structure risks, that is, high leverage and short debt maturity, were significantly more likely to reduce leverage and extend debt maturity, as were those REITs with stronger corporate governance. On balance, our evidence is therefore consistent with the interpretation of riskreducing changes in capital structure ahead of the financial crisis as a component of managerial skill and discipline rather than luck.

As a falsification test, we investigate whether any of these results hold in a sample of European REITs. Since excessive real estate lending prior to 2007 was arguably predominantly a US phenomenon, shareholders of European REITs should not reward risk reductions in capital structure in the same way as in the US. As expected, we find that none of our results hold in the European sample. In other words, our find- 
ings suggest that European REITs that reduced leverage or extended debt maturity before the financial crisis received no benefit during the financial crisis.

Overall, our findings suggest that US REIT managers were able to observe warning signals of an impending crisis prior to 2007, generating an opportunity to reduce capital structure risks. Our findings further suggest that such adjustments to capital structure were perceived as a positive signal by shareholders. On the other hand, we find that adjusting risky capital structure in Europe was not rewarded by shareholders in the same way it was in the US. This finding seems intuitive as the European REIT market was not subject to the same levels of real estate lending as the US markets prior to the financial crisis in 2007-2009. However, we note that the sample size for the European REITs is smaller than for the US REITs, and interpret the corresponding results with caution.

We proceed as follows. Section 2 reviews the related literature. Section 3 develops our testable hypotheses. Section 4 discusses the role of corporate governance in the context of our study. Section 5 describes data and empirical method. Section 6 discusses our empirical results. Section 7 presents robustness tests. Section 8 concludes.

\section{Empirical links between capital structure and firm performance}

Traditional theory predicts a positive relationship between leverage and equity risk, raising the required return on equity (Modigliani and Miller, 1958). Empirical research broadly agrees on the significance of leverage for equity returns (Choi, 2013; Garcia-Feijóo and Jorgensen, 2010; Garlappi and Yan, 2011; Gomes and Schmid, 2010; Obreja, 2013), but the direction of its effect is unresolved. Bhandari (1988) and Fama and French (1992) find the expected positive relationship between leverage and returns. More recent research however finds an inverse relationship (Dimitrov and Jain, 2008; George and Hwang, 2010; Penman, Richardson, and Tuna, 2007). ${ }^{1}$

Similarly, little definitive evidence is available on the relationship between leverage and returns in real estate firms. Again, some find an inverse relationship (Cheng and Roulac, 2007; Giacomini, Ling, and Naranjo, 2015b; Ling and Naranjo, 2015; Sun, Titman, and Twite, 2015), while others find a positive relationship (Giacomini, Ling, and Naranjo, 2015a), and others yet find no evidence for a significant relationship (Pavlov, Steiner, and Wachter, 2015).

1 Others find that the relationship is non-linear (Garlappi, Shu, and Yan, 2008; Korteweg, 2010), or conditional on the firm's distance from optimal target leverage (Hull, 1999; Steri, Ippolito, and Tebaldi, 2012). 
Furthermore, some authors have explored the link between leverage and risk directly. In relation to systematic risk, Allen, Madura, and Springer (2000) argue that financial leverage magnifies the firm's equity returns when the return on the market is positive. Conversely, their argument continues that leverage also magnifies negative returns, creating more pronounced losses. This line of reasoning is consistent with the argument in Goetzmann, Ingersoll, Spiegel, and Welch (2007) that leverage increases the firm's exposure to variation in the return on the market. Empirically, Sun and Yung (2009) find mixed evidence on the relation between leverage and REIT total volatility. Chaudhry, Maheshwari, and Webb (2004) find that leverage drives REIT idiosyncratic risk but the direction of the effect is sensitive to model specification.

In this study, we extend the evidence for the relationship between and REIT performance in the financial crisis of 2007-2009 that is presented in Sun, Titman, and Twite (2015). The effect of leverage during a crisis is particularly relevant in light of the financial accelerator, which exacerbates the implications of a market decline through the tightening of credit conditions (Bernanke and Gertler, 1989; Bernanke, Gertler, and Gilchrist, 1996; Kiyotaki and Moore, 1997; Perez-Quiros and Timmermann, 2000). Tighter credit conditions disproportionately affect firms with higher leverage. REITs as an industry tend to be consistently more highly levered than standard industrial firms (Barclay, Heitzman, and Smith, 2013; Harrison, Panasian, and Seiler, 2011). In addition, the REIT payout requirement means that REITs are unable to rely on internal cash reserves to absorb liquidity shocks (Ott, Riddiough, and $\mathrm{Yi}, 2005$ ), increasing the need for proactive leverage choices to maintain financial flexibility. ${ }^{2}$ Therefore, exploring the ways in which managers may adjust their leverage position to improve the resilience of their firms in periods of financial turmoil is particularly important in light of these characteristics of the REIT industry.

\section{Hypothesis development}

One of the most widely accepted predictions of traditional capital structure theory is that firms with higher volatility face a higher probability of bankruptcy. ${ }^{3}$ Therefore, firms facing higher volatility should carry lower leverage. While the tra-

\footnotetext{
2 This link is highlighted, for instance, in Almeida, Campello, and Weisbach (2011); DeAngelo and DeAngelo (2007); DeAngelo, DeAngelo, and Whited (2011); Denis and McKeon (2012); and Holmström and Tirole (2011). A review of this literature is provided in Denis (2011).

3 Early studies generating this conclusion include Modigliani and Miller (1958), Scott (1976), Brennan and Schwartz (1984) and Leland (1994), among others.
} 
ditional literature only considers constant volatility, Chen, Wang, and Zhou (2014), among others, interpret this to mean that "firms will adjust their leverage downward (upward) when they expect that volatility has risen (fallen)" (p. 4).

More recent studies that focus on stochastic volatility or regime switching of the volatility in firm cash flows or asset values, such as Chen and Kou (2009) and Elliott and Shen (2015), confirm that firms reduce leverage when the expected future volatility of cash flows or underlying assets increases. While this result seems intuitive, capturing signals of changes in the future volatility of asset values or cash flows is not trivial. Consider a manager who receives a noisy signal of the change in future volatility, $\Delta \hat{\sigma}_{i, t}$ :

$$
\Delta \hat{\sigma}_{i, t}=\sigma_{i, t+1}+\tilde{\epsilon}_{i, t+1}
$$

where $i$ denotes a particular manager, $t$ denotes the current time period and $\Delta \sigma_{i, t}=$ $\sigma_{i, t+1}-\sigma_{i, t}$ measures the true unobservable change in volatility going forward. Managers differ in the precision with which they perceive signals of changes in future volatility, that is in the variance of the noise component, $v_{i}^{2}=\operatorname{var}\left(\tilde{\epsilon}_{i, t+1}\right)$, which is not observable by shareholders. Each period managers receive a noisy signal about future volatility and adjust their capital structure according to this signal. This adjustment is attenuated relative to the outcome of the structural models in the literature because managers recognise that their future volatility estimate is noisy. Let $g\left(\Delta \hat{\sigma}_{i, t}, v_{i}^{2}\right)$ denote the function managers use to decide on the amount and direction of change in leverage in view of the signal about the future change in volatility. This function depends on the variance of the noise. Managers who receive noisy signals adjust their capital structure very little even if their signal indicates a substantial change in the future, so that

$$
\frac{\partial^{2} g\left(\Delta \hat{\sigma}_{i, t}, v_{i}^{2}\right)}{\partial \Delta \hat{\sigma}_{i, t} \partial v_{i}^{2}}<0
$$

In other words, the change in leverage in response to a signal is a decreasing function of noise variance. This in theory leads to the following hypothesis: Managers who adjust their capital structure more in response to a signal about a change in future volatility have more precise signals. However, this hypothesis is not testable because shareholders do not observe the signal each manager receives.

Instead, shareholders need to rely on the actual change in volatility, once it is observed. This leads to the following hypothesis: Managers who adjust their capital 
structure more in response to the actual change in volatility have more precise signals. Since the actual change in volatility is only observable after the change has occurred, the second hypothesis is only testable ex-post.

Even with this, testing the latter hypothesis presents two difficulties. First, it is testable only if the change in volatility is large relative to the variance of the noise. For instance, it may be tested during a crisis, but not during normal economic conditions. Second, empiricists do not observe the precision of the signals that managers receive. One way to estimate the precision of the signals the managers receive, which reflects an important managerial skill, is to use the stock performance when managerial actions and the size of the actual change in volatility are revealed. If managerial actions were consistent with the change in volatility, then the precision of the signal for that manager is revealed and its value is incorporated into the stock price. This discussion leads to the following empirically testable hypothesis:

Hypothesis 1: Firms whose managers adjust capital structure more in response to large changes in future volatility have higher stock returns when the consequences of their actions and the actual change in volatility are revealed.

Inevitably, some managers with typically precise signals may receive an imprecise signal purely by chance. Similarly, some managers with typically imprecise signals may receive a strong signal and as a consequence react appropriately. In other words, some managers may be particularly lucky or unlucky in adjusting their capital structure at the right time. In conclusion, we expect that on average, REITs whose managers adjusted the firm's capital structure more experience higher stock returns in the period when the consequences of their actions are revealed.

While we are unlikely to be able to fully distinguish between managerial skill and luck in adjusting capital structure in response to a signal of a change in future volatility, we nevertheless explore the evidence for two related hypotheses. We will argue that empirical support for these hypotheses is on balance more consistent with managerial skill rather than luck as the dominating driver behind capital structure adjustments prior to a change in volatility.

First, if a signal about an increase in future volatility is correct and precedes and actual increase, then firms with higher leverage and more refinancing risk (shorter debt maturity) will be affected disproportionately by the eventual volatility shock, as a result of the financial accelerator effect. Therefore, if there is managerial skill involved 
in driving adjustments to capital structure choices prior to an expected increase in volatility, then it seems plausible that this skill also extends to the recognition of the firm's financial risk. As a result, we expect capital structure adjustments in response to a signal about an increase in future volatility to be larger for firms that currently face higher capital structure risks, i.e. those firms with higher leverage and shorter debt maturity. This discussion leads to the the second testable hypothesis.

Hypothesis 2(a): Firms with higher capital structure-related risks, i.e. firms with higher leverage and shorter debt maturity, are more likely to adjust their capital structure when expecting large changes in future volatility.

Second, another component that distinguishes lucky adjustments in capital structure prior to a change in asset value or cash flow volatility from systematic adjustments that relate to management quality is corporate governance. If corporate governance is strong, then we argue that, consequently, managers are well incentivised to observe signals about changes in future volatility carefully in order to adjust the financial position of their firm in a way that enables the firm to be resilient to any future financial shocks. Therefore, we expect capital structure adjustments in response to a signal about an increase in future volatility to be larger for firms that have strong corporate governance. We further elaborate on the role of corporate governance in capital structure choices in the next section. This discussion leads to the final testable hypothesis.

Hypothesis 2(b): Firms with strong corporate governance are more likely to adjust their capital structure when expecting large changes in future volatility.

As noted, outsiders are unable to observe any signals that managers may perceive about changes in future volatility. As a result, empiricists need to rely on actual changes in volatility. These actual changes in volatility also need to be large to be empirically observable to a noticeable degree of significance. Therefore, we use the period around the 2007/2008 financial crisis to test our hypotheses. Specifically, we use the change in leverage in the pre-crisis period (over the year of 2006) and the stock return over the subsequent period during which the managerial actions and the size of the volatility increase were revealed (2007-2009). ${ }^{4}$

\footnotetext{
4 There are other historical temporal events, both in the US and abroad, that we would like to consider as additional robustness checks, especially given the relatively smaller small sample size in some of our tests. We acknowledge that evidence from these previous periods of high real estate market volatility would be useful to illustrate how shareholders benefitted from observing capital structure decisions made ahead of those periods, e.g. in the late 1980s and early 1990s. However, our data provider, SNL Financial, does not cover this period for international REITs, or indeed a large and comprehensive sample of US REITs.
} 
This discussion is phrased in terms of changes in leverage. However, there are other capital structure adjustments that may serve the same purpose. Consistent with Sun, Titman, and Twite (2015), we focus on the role of debt maturity alongside that of leverage. Managers who receive more precise signals about future volatility may reduce refinancing risk by extending debt maturity. As a result, we expand hypotheses (1) and 2(a) to 2(b) to the amount and direction of changes in debt maturity, measured as the share of debt due in 2-3 years.

\section{The role of corporate governance}

In our empirical analysis, we analyse the cross-section of financing choices prior to the financial crisis of 2007-2009 as a function of corporate governance. We examine this relationship for the following reasons. Grossman and Hart (1983) develop a model for the firm's financing choice in the presence of agency conflicts between shareholders and managers. More recently, Novaes and Zingales (1995) show that the optimal choice of debt from the viewpoint of shareholders differs from the optimal choice of debt from the viewpoint of managers. Bhagat and Bolton (2008) summarise the reasons for this difference: (i) shareholders are more diversified than managers whose human capital is tied to the firm (Fama, 1980); (ii) debt is a disciplining divide for managers (Jensen, 1986); and (iii) Harris and Raviv (1988) and Stulz (1988) argue that managers increase leverage to increase their voting power and reduce takeover risk. ${ }^{5}$ As a result, we expect that corporate governance has an influence on the way in which managers make financing choices. ${ }^{6}$

The next set of questions relates to the measurement of corporate governance, that is, (i) the number of provisions to be included, (ii) the most appropriate data source, and (iii) the most appropriate timing of the observations on those provisions. Gompers, Ishii, and Metrick (2003) are the first to document a systematic relationship between a comprehensive measure of corporate governance, labelled the G-index, and firm performance. They develop their governance measure as an equally-weighted index of 24 provisions that restrict shareholder rights. Cremers and Nair (2005) use

There are other periods of real estate market declines across the world, for instance the 1997 Asian financial crisis. However, we found it difficult to obtain international data for those periods that reliably capture the required variables in the relevant countries.

5 In addition to this literature on capital structure and managerial entrenchment, a different body of research examines the relation between capital structure and ownership structure as well, e.g. Grossman and Hart (1986) and Hart and Moore (1990).

6 It may be argued that corporate governance provisions are less significant in REITs because of their strict regulatory environment. However, Bauer, Eichholtz, and Kok (2010), Hartzell, Kallberg, and Liu (2008) Hartzell, Sun, and Titman (2006) confirm that firm-level corporate governance still has a significant impact on REIT corporate financial decisions, stock valiant and performance outcomes. 
similar data to compile a governance measure that distinguishes between internal and external governance. However, Bebchuk, Cohen, and Ferrell (2009) argue that some of these provisions may be correlated. Therefore, they focus on a subset of the 6 provisions to develop an entrenchment index, labelled E-index, based on information about staggered boards, limits to shareholder bylaw amendments, poison pills, golden parachutes, and supermajority requirements. They find that these are the most significant provisions in the determination of firm value. This finding suggests that a small number of governance provisions is able to capture the majority of the impact of governance on corporate financial outcomes.

The data used in Gompers, Ishii, and Metrick (2003), Bebchuk, Cohen, and Ferrell (2009) and Cremers and Nair (2005) is compiled by the Investor Responsibility Research Center (IRRC). Brown and Caylor (2006) develop a governance index using data from Institutional Shareholder Services (ISS). This index is comprised of 52 corporate governance provisions. The results are qualitatively similar across those studies, suggesting that governance provisions are easily observed and the exact source of the data is of little concern to the accuracy of the measurements.

Lastly, the G-index based on the IRRC data used by Gompers, Ishii, and Metrick (2003) has been discontinued in 2007 after the acquisition of IRRC by ISS Risk Metrics. More recent studies, such as Guiso, Sapienza, and Zingales (2015) assign the most recent value available from IRRC to their sample firms from 2007 onwards. This approach of focusing on recent cross-sectional variation in governance provisions is further supported by the observation that most time series variation in corporate governance occurred in the 1980s (Cremers and Ferrell, 2014).

As a result of this discussion, we obtain information on the firm's corporate governance provisions as follows. First, we use data from $S N L$. The former IRRC, now ISS Risk Metrics data covers the 1,500 largest US corporations. As a result, the coverage for REITs is not comprehensive, because typical REIT firm size is smaller. The $S N L$ data allows us to obtain governance data on more REITs. The provisions covered by $S N L$ are consistent with those covered in data bases such as IRRC (until 2007 ) or ISS. They include a sub-set of the 24 provisions in the original G-index, and also fewer than in the E-index, but they are current observations. The included provisions are staggered board, poison pill, and supermajority requirements. Overall, we believe that the benefit of the availability of current observations on these important provisions for a broader set of firms outweighs that of having a larger 
number of provisions available but for a smaller set of firms, which may also be stale, as in the case of the IRRC legacy data.

The presence of these three provisions, staggered board, poison pill, and supermajority requirements, restricts shareholder rights. Following the methodology in Gompers, Ishii, and Metrick (2003), we calculate a governance score by starting from zero and adding a point for the presence of each provision. A higher governance score thus indicates a more dictatorial firm with weaker shareholder rights. This variable allows us to assess the impact of corporate governance on capital structure choices in the run-up to the financial crisis of 2007-2009.

We calculate the SNL good governance indicator on the basis of the SNL governance score by splitting its distribution in 2006 along the median. Firms in the lower part of the distribution have fewer provisions that restrict shareholder rights. We assign those firms an SNL good governance indicator value of 1 , and zero otherwise. In order to support the suitability of our measure of corporate governance empirically, we construct a scatter plot of the REIT discount/premium to NAV as a function of the SNL good governance indicator. Figure 1 shows a slightly upwards sloping relationship between the SNL governance indicator and the price/NAV ratio, suggesting that firms with a more shareholder-friendly governance structure are valued more highly relative to the value of their underlying assets.

[Insert Figure 1 here.]

\section{Data and method}

\subsection{Data set and descriptive statistics}

We study all listed US and European equity REITs on SNL Financial as of the end of 2005. We analyse capital structure choices in the year leading up to the financial crisis in 2007 , i.e. capital structure choices over the year 2006. Individual firm data is obtained from $S N L$ Financial.

We measure the variables in our analysis following Sun, Titman, and Twite (2015). Performance during the financial crisis is measured as the cumulative monthly rates of total return for the time period January 2007 to February 2009, winsorised at the 2 nd and 98th percentiles to mitigate any undue influence of outliers. We focus on leverage and debt maturity because the evidence for the impact of variable-rate 
debt in Sun, Titman, and Twite (2015) is mixed. We measure the change in leverage over the year 2006 as the first difference of market leverage. ${ }^{7}$ Market leverage is the ratio of total debt (book value of short-term and long-term interest bearing debt) to market value of invested capital. Market value of invested capital is the sum of total debt, preferred stock and market capitalisation (number of shares outstanding multiplied by the end-of-period share price). For US REITs, we measure the change in debt maturity as the first difference of the share of debt due in 2-3 years. For European REITs, we use the change in the share of debt due in 1-5 years, as European REITs do not report a year-by-year debt schedule.

As control variables, we include: the level of leverage and the share of debt due in 2-3 years, firm size (log of market capitalisation), Tobin's q (ratio of firm market value, i.e. market capitalisation plus total assets less book value of equity, to total assets), and the cash-to-assets ratio (cash and cash equivalents to total assets).

Table 1 presents summary statistics as of the end of 2006. ${ }^{8}$ On average, the US sample firms reduced leverage and debt (due in 2-3 years) over the year 2006. However, variation around the means is significant, with a standard deviation of 0.07 for leverage and 0.24 for debt maturity, suggesting that capital structure choices during 2006 varied substantially across firms. The European firms in our sample on average reduced leverage over the year 2006 by the same amount as US firms, with the same standard deviation. It appears that the European firms have increased the share of debt due in 1-5 years. However, this measure is a noisy indicator of debt due during the financial crisis, as reporting rules only require European firms to disclose the amount of debt due in 1-5 years, rather than on an annual basis. The levels of leverage are similar across the US and European firms (0.39 versus 0.35 ), but the debt maturity measures are not comparable, due to reporting differences. The mean of the SNL governance score is lower in the US than in Europe $(0.34$ versus 0.59), suggesting strong shareholder rights in the US. European REITs are on average smaller than in the US (log of firm size of 13.98 to 14.20), have a lower Tobin's q (1.15 versus 1.55), hold similar levels of cash-to-assets (0.03) and have experienced a similar cumulative total return over the period of the financial crisis 2007-2009 (-0.56 and -0.59).

\footnotetext{
7 Leverage ratios may be driven by denominator effects through the market cycle. However, we assume that REIT managers are aware of this effect and factor it into their capital structure choices through time. 8 The firms in our sample cover the sectors Diversified, Health Care, Hotel, Office, Residential, Retail and Specialty. Descriptive statistics by property sector are provided in the Appendix, see Tables A.1 and A.2 for the US firms, and Tables B.1 and B.2 for the European firms, respectively.
} 
[Insert Table 1 here.]

Table 2 presents pairwise correlation coefficients between the variables in our study. We find significant inverse correlations between the cumulative total return and a number of firm characteristics in the US, especially leverage and debt maturity, consistent with the observations in Sun, Titman, and Twite (2015). In addition, we find inverse relationships between a reduction in leverage and a reduction in debt maturing in the 2007-2009 period, which is inconsistent with our hypothesis. Furthermore, larger firms seem to have experienced a lower cumulative total return over the period in question. However, pairwise correlation does not measure the marginal impact of reducing leverage or adjusting the debt maturity profile of the firm.

In the European sample, the only significant pairwise correlation is a positive relationship between corporate governance and the cumulative total return, but again, we explore marginal effects in the conditional analysis. Furthermore, Table 2 shows levels of correlation below 0.8 among the main predictors of interest, alleviating concerns about multicollinearity.

[Insert Table 2 here.]

\subsection{Empirical method}

Capital structure choices in 2006 and performance during the financial crisis

In order to test hypothesis 1, we examine the extent to which the capital structure adjustments that REIT managers made during 2006 are related to REIT performance in terms of the cumulative total return during the subsequent crisis period 2007-2009. In order to explore the effect of leverage choices, we estimate the following cross-sectional regression for the US REITs in our sample using OLS:

$$
C T R_{i}=\beta_{0}+\beta_{1} D \cdot M \operatorname{Lev}_{i}+\beta_{2} M \operatorname{Lev}_{i}+\beta_{3} L_{N S i z e_{i}}+\beta_{4} Q_{i}+\beta_{5} \text { Cash }_{i}+u_{i}
$$

where $\beta_{0}$ is a constant, $\beta_{j}$ is the regression coefficient corresponding to the explanatory variable $j$ and $u$ is the residual. Subscript $i$ refers to firm $i$. $C T R$ is the cumulative total return 2007-2009. D.MLev is the change in market leverage during 2006. MLev is the level of market leverage at the end of 2006, capturing the effect documented in Sun, Titman, and Twite (2015). LNSize is the log of firm size, $Q$ is Tobin's q, and Cash is the cash-to-assets ratio, all measured as of the end of 2006. 
We also include sector fixed-effects and report heteroskedasticity-robust standard errors.

We perform a falsification test using European REIT data over the same time period. Recall from Table 1 that European REITs generally experienced smaller declines over the 2007-2009 period than their US counterparts. Yet, the decline in the European REIT market was still substantial and thus likely qualifies under the definition of a significant change in volatility in hypothesis 1 . However, European real estate markets did not experience the same level of real estate lending prior to the financial crisis. Therefore, a European REIT manager was less likely to observe a strong signal about an increase in future volatility than a US manager. As a result, a pre-crisis reduction in leverage does not contain the same information for a European REIT as it does for a US REIT. In short, the relationship in hypothesis 1 should not hold for European REITs.

We explore the effect of changes in debt maturity using regression (3) but we replace the change in leverage with the change in debt due in 2-3 years during 2006, D.Mat23, as follows:

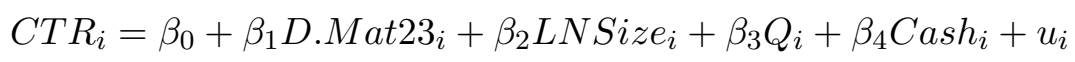

Further, in order to explore the relationships of interest in the European firms in our sample, we run the regressions for these firms separately. In the debt maturity equation, we replace the variable measuring the change in debt due in 2-3 years during 2006 with the change in debt due in 1-5 years during 2006, D.Mat15. We estimate the following model:

$$
C T R_{i}=\beta_{0}+\beta_{1} D \cdot{\text { Mat } 15_{i}}_{i}+\beta_{2} L N \text { Size }_{i}+\beta_{3} Q_{i}+\beta_{4} \text { Cash }_{i}+u_{i}
$$

\section{Cross-sectional analysis}

In order to test hypothesis 2 , and distinguish between managerial skill and luck that may have determined the changes in capital structure in 2006, we examine the question whether those firms that were more at risk were aware of their situation and were more likely to adjust their capital structure to a more robust position in the run-up to the financial crisis. We estimate the following logit model for the US 
REITs in our sample:

$$
\operatorname{Red}_{i}=\beta_{0}+\beta_{1} L \cdot M \text { Lev }_{i}+\beta_{2} L \cdot L N \text { Size }_{i}+\beta_{3} L \cdot Q_{i}+\beta_{4} L \cdot \text { Cash }_{i}+u_{i}
$$

where $\beta_{0}$ is a constant, $\beta_{j}$ is the coefficient of the explanatory variable $j$ and $u$ is the residual. Red is the likelihood that a firm reduced leverage by 0.05 or more in 2006. While this cut-off level is arbitrary, it does capture the notion that the leverage reduction needs to be substantial to be identified as a clear managerial choice. For robustness, we employ a range of alternative cut-off levels, including including the mean and median of leverage reductions. L.MLev is the lag of leverage, measured at the end of 2005. LNSize is the lagged log of firm size, $Q$ is lagged Tobin's q, and Cash is the lagged cash-to-assets ratio, all measured as of the end of 2005. If firms with higher leverage were aware of their situation and took precautionary measures to de-lever in the run-up to the financial crisis, then we expect $\beta_{1}$ to be positive and significant. We also include sector fixed-effects. As before, we run the regressions for the US and European sample firms separately.

In order to explore the likelihood that firms extend short debt maturity, we run regression (6) and replace the dependent variable with the likelihood that a firm reduced the share of debt due in 2-3 years by 0.05 or more in 2006, D. Mat23. Again, the choice of $5 \%$ is specific but the sign and significance of $\beta_{1}$ are robust to various cut-off values, including the mean and median of the variable. The main variable of interest is the lagged share of debt due in 2-3 years, L.Mat23. If firms with short debt maturity were aware of their refinancing risk and adjusted capital structure accordingly, then we expect the coefficient on L.Mat23 to be positive and significant. As before, we include sector fixed-effects. We estimate the following model:

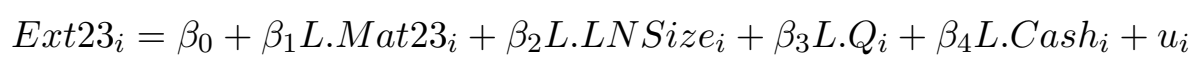

Again, we examine the European sample firms separately. In the debt maturity equation, we replace the Ext23 variable with the likelihood that a firm extended debt maturity through reducing the share of debt due in 1-5 years by 0.05 or more in 2006, Ext15. The main dependent variable of interest is the share of debt due in 1-5 years in 2005, L.Mat15. If European REITs with short debt maturity were aware of their refinancing risk and adjusted capital structure accordingly, then we expect the coefficient on the variable L.Mat15 to be positive and significant. As 
before, we include sector fixed-effects to account for unobservables and estimate the following model:

$$
\operatorname{Ext}_{1} 5_{i}=\beta_{0}+\beta_{1} \text { L.Mat } 15_{i}+\beta_{2} \text { L.LNSize } i+\beta_{3} L \cdot Q_{i}+\beta_{4} L . \text { Cash }_{i}+u_{i}
$$

Finally, we explore the role of corporate governance on the extent to which REITs with risky capital structures took precautionary measures to create more robust capital structures in the run-up to the financial crisis. In this analysis, we create interaction terms with the capital structure variables that put firms at risk from a financial shock as suggested in Sun, Titman, and Twite (2015). For the US part of the sample, we create an indicator/interaction term for those firms that had abovemedian leverage or above-median shares of debt due in 2-3 years at the end of 2005 . We estimate the following logit model for the sample of US REITs:

$$
\begin{aligned}
\text { Red }_{i} & =\beta_{0}+\beta_{1} \text { HighLev }_{i} * \text { StrongGov }_{i}+\beta_{2} \text { L.MLev }_{i}+\beta_{3} \text { L.SNLGov } \\
& +\beta_{4} L . L N \text { Size }_{i}+\beta_{5} L . Q_{i}+\beta_{6} \text { L.Cash }_{i}+u_{i}
\end{aligned}
$$

where L.SNLGov is the lag of the $S N L$ governance score as of the end of 2005, and the other coefficients and variables are defined as in (6). If stronger shareholder rights help rein in excessive leverage, then we expect a positive and significant coefficient on the interaction variable with an indicator based on below-average values of L.SNLGov, where a higher governance score indicates weaker shareholder rights. Similarly to (9), we estimate this model for the likelihood to extend debt maturity for US sample REITs:

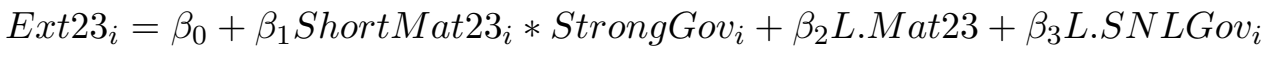

$$
\begin{aligned}
& +\beta_{4} L . L N \text { Size }_{i}+\beta_{5} L . Q_{i}+\beta_{6} \text { L.Cash }_{i}+u_{i}
\end{aligned}
$$

where coefficients and variables are defined as in (9). As before, we include sector fixed effects in all of these regressions. For the European sample firms, we estimate:

$$
\begin{aligned}
& \operatorname{RedEur}_{i}=\beta_{0}+\beta_{1} \text { HighLev }_{i} * \text { StrongGov }_{i}+\beta_{2} \text { L.MLev }_{i}+\beta_{3} \text { L.SNLGov } i \\
& +\beta_{4} L . L N \text { Size }_{i}+\beta_{5} L . Q_{i}+\beta_{6} L . \text { Cash }_{i}+u_{i}
\end{aligned}
$$

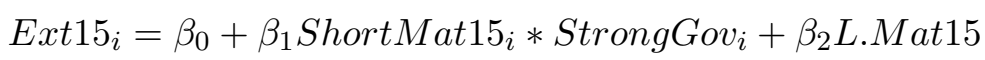

$$
\begin{aligned}
& +\beta_{3} \text { L.SNLGov }_{i}+\beta_{4} \text { L.LNSize }_{i}+\beta_{5} L . Q_{i}+\beta_{6} \text { L.Cash }_{i}+u_{i}
\end{aligned}
$$




\section{Results}

\subsection{Unconditional analysis}

We begin by exploring the relationships between REIT characteristics and leverage choices using an unconditional, multivariate analysis. In Table 3 we sort observations into quintiles ranked by market leverage, with quintile 1 containing the lowest leverage firms and quintile 5 containing the highest leverage firms. We tabulate the corresponding mean firm characteristics in each quintile and then test the hypothesis that these means differ significantly across the top and bottom quintiles.

\section{[Insert Table 3 here.]}

Table 3 shows that firms with high leverage tended to see their leverage increase in 2006. Beyond that, the only firm characteristic that the sample firms with high leverage have in common is a lower Tobin's q ratio. If we interpret Tobin's q as a measure of growth opportunities, then our finding reflects that firms with higher growth opportunities have lower levels of leverage in order to avoid agency costs of underinvestment (Myers, 1977). There is no evidence of significant relationships between leverage and firm characteristics in the European sample.

Next, we graphically explore the relationships between REIT capital structure choices and the cumulative total return 2007-2009. Figure 2 (3) shows the results for the US (Europe). Panels (a) and (b) of Figure 2 show the downward sloping relationship between the levels of leverage and the share of debt due in 2-3 years, respectively, and the cumulative total return on US REITs during the period 2007-2009. This downward sloping relationship is consistent with the findings presented in Sun, Titman, and Twite (2015) and Giacomini, Ling, and Naranjo (2015a). However, Panels (c) and (d) show of Figure 2 additionally show a downward sloping relationship between changes in leverage and the share of debt due in 2-3 years, respectively, and the cumulative total return 2007-2009. This finding is consistent with hypothesis 1, that precautionary adjustments to capital structure choices contributed to the cumulative total return during the financial crisis of 2007-2009.

\section{[Insert Figure 2 here.]}

Figure 3 shows the corresponding relationships for the European REITs. Panel (a) shows a downward sloping relationship between leverage and firm performance in 2007-2009. This observation extends the evidence presented in Sun, Titman, and 
Twite (2015) from the US to international REITs. However, Panel (b) shows a flat relationship between European REIT performance and the share of short-term debt due during the financial crisis, suggesting that the debt maturity policy of European REITs was less correlated with firm performance during the financial crisis. Panels (c) and (d) show the relationships between the changes in leverage and the share of debt due during the financial crisis, respectively, and firm performance 2007-2009. These plots show slightly upward sloping relationships. The lack of a negative relationship between changes in leverage and the cumulative total return for the European REITs is consistent with expectations. However, we report this result with caution, as it is based on a relatively smaller sample. Nevertheless, we take comfort in the observation that the relationship between change in leverage and return is actually positive and significant, rather than non-existent. Despite the small sample, this makes it less likely that the true relationship is negative, as we find for US REITs.

\section{[Insert Figure 3 here.]}

In order to explore the relationships between REIT capital structure choices and the cumulative total return 2007-2009 further, we sort observations into quintiles ranked by the cumulative total return 2007-2009, with quintile 1 containing the firms with the lowest return and quintile 5 containing the with the highest return. We tabulate the corresponding capital structure choices, in levels and changes, in each quintile and then test the hypothesis that the means differ significantly across the top and bottom quintiles. Table 4 shows the results.

\section{[Insert Table 4 here.]}

This preliminary unconditional analysis suggests that firms with lower leverage and a lower share of debt due during the financial crisis achieved a higher cumulative total return during 2007-2009. This finding is consistent with Sun, Titman, and Twite (2015) and Giacomini, Ling, and Naranjo (2015a). Additionally, firms that reduced their leverage and the share of debt due during the financial crisis over the course of 2006 also registered a numerically higher cumulative total return during the financial crisis. The difference between the top and bottom quintiles does not pass the threshold for statistical significance. However, this unconditional analysis does not measure marginal effects and is thus unable to account for any correlation between the levels of the capital structure variables of interest and changes in those variables. In this unconditional analysis, we generally find no evidence of significant 
associations between the cumulative total return 2007-2009 and capital structure choices in the European sample. With these preliminary results in mind, we now turn to the conditional analysis. ${ }^{9,10}$

\subsection{Conditional analysis}

Table 5 presents the main regression results. ${ }^{11}$ The dependent variable is the cumulative total return over the period 2007-2009. In Column 1, the main variable of interest is the change in market leverage from the end of 2005 to the end of 2006 . We find that the coefficient on this variable is negative and significant at the $5 \%$ level. This finding is robust to including the level of market leverage at the end of 2006 and the set of control variables. ${ }^{12}$ The main finding of our analysis is therefore consistent with hypothesis 1: Reducing leverage before the financial crisis (over the year 2006) was associated with a higher cumulative total return for US REITs during the financial crisis (2007-2009).

[Insert Table 5 here.]

The impact of changes in leverage before the financial crisis on the cumulative total return during the financial crisis is also economically significant. The estimated coefficient of -0.783 implies that a one percentage point reduction in leverage before the financial crisis was associated with a 78 basis points increase in cumulative total return during the financial crisis. Reducing leverage by one standard deviation (seven percentage points) was associated with an increase in the cumulative total return during the financial crisis of $5.5 \%$. Given the size of the REIT industry, this change translates into a potential US $\$ 10$ billion of additional market value at the end of the financial crisis.

Column 2 of Table 5 suggests that an extension of debt maturity, measured as a reduction in the share of debt due in 2-3 years, was also associated with a higher cumulative total return for US REITs during the financial crisis 2007-2009. This finding is also consistent with hypothesis 1 .

\footnotetext{
9 We have replicated this analysis using the median of the cumulative total return and capital structure variables instead. The results, shown in Appendix C.1, are qualitatively similar, except that the level of debt due in 2-3 years in the US firms loses significance. In return, the change in leverage gains significance. This finding is consistent with hypothesis 1 , that precautionary reductions in leverage were associated with a higher cumulative total return 2007-2009.

10 For completeness, we have also replicated this analysis using the changes in leverage and debt maturity over the year 2006 as the sorting variable for the US and European REITs in the sample. Results are presented in Appendix C.2 and C.3, respectively.

11 The descriptive statistics for the regression sample used in Table 5 are provided in Appendix D.1.

12 It is also robust to including lagged market leverage (not reported).
} 
Columns 3 and 4 of Table 5 examine hypothesis 1 in the sample of European REITs. Recall that we do not expect a reduction in leverage or extension of debt maturity to be associated with a higher cumulative total return for European REITs. Consistent with this expectation, we find that neither reductions in leverage nor adjustments to the share of debt due in $2-3$ years ${ }^{13}$ were associated with a significantly higher cumulative total return for European REITs during the financial crisis 2007-2009. While we interpret the coefficient estimates with caution due to the smaller sample size, these findings are generally consistent with expectations.

However, there may be unobserved factors that drives both changes in leverage and the subsequent cumulative total return 2007-2009, or the relationship may reflect pure luck. Therefore, we now examine systematic cross-sectional differences between the firms that were more likely to adjust their capital structure prior to the financial crisis and those that were less likely to do so, as per hypothesis 2(a). Table 6 shows the results. ${ }^{14}$

[Insert Table 6 here.]

We find that firms that were more exposed to capital structure risks in terms of high leverage and short debt maturity prior to the financial crisis were more likely to reduce those capital structure risks. Column 1 reports that firms with high leverage were more likely to reduce leverage prior to the financial crisis. Column 2 presents the result that firms with higher shares of debt due in 2-3 years were more likely to reduce this exposure. Both coefficients are significant at the $1 \%$ level, and robust to the inclusion of our control variables. While this result is based on the $5 \%$ cut-off level used to identify firms that reduced leverage or the share of debt maturing in 2-3 years, the significance of the market leverage and debt maturity variables is robust to a range of cut-off values for the dependent variables, including their mean and median (nor reported). Furthermore, consistent with expectations, neither result holds for the European sample.

We further investigate whether firms with stronger corporate governance were more likely to prepare for the financial crisis. This analysis refers to hypothesis 2 (b). Table 7 presents the results.

\footnotetext{
13 We note that this result is not robust to including the level of debt due in $2-3$ years at the start of the financial crisis. If both the change and the level are included in the regression, neither is significant. This is due to the correlation between the change in the share of debt due in 2-3 years and its level at the start of the financial crisis.

14 The descriptive statistics for the regression sample used in Tables 6 and 7 are provided in Appendix E.1.
} 
[Insert Table 7 here.]

Column 1 of Table 7 reports that an interaction variable that takes the value of 1 if market leverage and governance are above the median and 0 otherwise is significant at the $10 \%$ level. Consistent with expectations, our finding suggests that highly levered firms that had stronger governance were more likely to reduce leverage. This result holds when controlling for market leverage and the main effect of the governance score. Again, as expected, we do not find this result for European REITs.

To summarise, our findings suggest that US REITs that reduced capital structure risks prior to the financial crisis achieved a higher cumulative total return 2007-2009. In the cross-section, those REITs that were more exposed to capital structure risks, in terms of high leverage and short debt maturity, were more likely to reduce these risks, particularly if they had strong corporate governance mechanisms in place. As expected, we find none of these results in the European sample.

\section{Robustness tests}

Giacomini, Ling, and Naranjo (2015b) provide empirical evidence on the role of deviations from target leverage in driving REIT performance. In order to control for this possibility, we estimate optimal target leverage levels as a function of the sample firm characteristics considered in our study. We then compute deviations from estimated target leverage. We include these deviations as an alternative explanatory variable in the regressions for the cumulative total return 2007-2009. Our main findings are robust to this additional control variable. In the US, we find that the deviation from target leverage itself is negatively related to the cumulative total return 2007-2009, suggesting that firms carrying excess leverage relative to their characteristic-informed optimal target experienced a lower cumulative total return 2007-2009. The findings for the European REITs also remain unchanged from our main analysis. For the European REITs, target leverage also carries a negative sign but is not significant. Results are presented in Appendix F.1.

We perform a number of further robustness tests. As none of these additional tests result in significant alterations of our main findings, we do not tabulate the results but provide the relevant details below.

It is possible that capital structure choices prior to the financial crisis were subordinate to and thus driven by a different dominating objective, such as the ability 
to take advantage of a stronger financial position to exploit distressed investment opportunities that may present themselves as a result of the financial crisis in the future. In order to explore this possibility, we estimate the likelihood to acquire properties as well as the actual investment volume of our sample firms as a function of lagged changes in capital structure choices. However, we do not find evidence of a significant relationship, suggesting that changes in capital structure choices prior to the financial crisis were not endogenous in the sense that they were driven by the ulterior objective to take advantage of investment opportunities that present themselves as a result of distress during the financial crisis. Rather, observed changes in capital structure seem more consistent with managerial skill in adjusting the financial structure of the firm to be resilient to asset value or cash flow shocks.

In alternative specifications, we have controlled for measures of REIT debt rating as well as the estimated return on the underlying property values, with no material impact on our results. Additionally, Tobin's Q may be endogenous. Therefore, we replicate our regression analysis excluding this variable. Our results remain unchanged.

Further, it is possible that there is a certain level of natural variation in leverage whereas only large changes in this variable are related to the signals managers receive about changes to future volatility. In order to account for this possibility, we employ inter-quantile range (IQR) regression. An IQR model using 0.25 and 0.75 quantiles, with bootstrap robust standard errors, confirms our results.

We also re-estimate the model using outlier-robust regression with a tuning constant of 10 (or larger). Robust regression first eliminates all observations with Cook's distance greater than 1 , and then performs additional iterations to further reduce the potential influence of any outliers. Our main result is robust to this specification.

\section{Conclusion}

Our main conclusion is that US REITs that adjusted their capital structure ahead of the 2007-2009 financial crisis outperformed their peers during the financial crisis. This result holds after controlling for the capital structure characteristics at the start of the financial crisis. On balance, our evidence is consistent with the hypothesis that changes in leverage in the end reflect a component of managerial skill in reading market signals about significant changes in future volatility. There- 
fore, our findings imply that REIT managers are able to add value to their firm by dynamically adjusting capital structure in response to signals about future market conditions. In economic terms, our results suggest that one standard deviation reduction in leverage resulted in $5 \%$ higher cumulative return during the financial crisis.

Sun, Titman, and Twite (2015) find that risky capital structure characteristics, such as high leverage and a high share of debt due in the near future, significantly reduced the cumulative total return of US REITs over the 2007-2009 financial crisis. Our work extends this study by documenting that preparing ahead of the financial crisis also significantly influenced the cumulative return over the financial crisis period. We find that REITs which reduced leverage and increased debt maturity prior to the financial crisis achieved a higher cumulative total return during the financial crisis. In the cross-section, we find that US REITs with the highest capital structure risk (high leverage and short debt maturity) were more likely to take precautions by reducing leverage and extending debt maturity. This effect is especially strong for those REITs with strong corporate governance. In a falsification test, we find that none of our findings hold for European REITs. This finding seems intuitive as European REITs did not experience the levels of real estate lending observed in the US before the financial crisis.

Our finding that preparation ahead of the financial crisis mattered for REIT performance during the financial crisis suggests that shareholders use observable managerial actions to identify and reward skill. Our finding further implies that it is not only the financial state of a firm that matters for performance but also the path it took to reach that state, to the extent that this path reflects managerial skill in anticipating future market conditions. We conclude that shareholders identify and reward this forward-looking skill, driving our empirical findings. However, we acknowledge that there may be other channels that link pre-crisis adjustments to capital structure with subsequent performance. Identifying and directly testing such alternatives may be a fruitful avenue for future research. 


\section{References}

Allen, M. T., J. Madura, And T. M. Springer (2000): "REIT Characteristics and the Sensitivity of REIT Returns," Journal of Real Estate Finance and Economics, 21(2), 141-152.

Almeida, H., M. Campello, and M. S. Weisbach (2011): "Corporate financial and investment policies when future financing is not frictionless," Journal of Corporate Finance, 17(3), 675-693.

Barclay, M. J., S. M. Heitzman, and C. W. Smith (2013): "Debt and taxes: Evidence from the real estate industry," Journal of Corporate Finance, 20(0), $74-93$.

Bauer, R., P. Eichholtz, And N. KoK (2010): "Corporate governance and performane: The REIT effect," Real Estate Economics, 31(1), 1-29.

Bebchuk, L., A. Cohen, And A. Ferrell (2009): "What matters in corporate governance?," Review of Financial studies, 22(2), 783-827.

Bernanke, B., And M. Gertler (1989): "Agency Costs, Net Worth, and Business Fluctuations," American Economic Review, 79(1), 14-31.

Bernanke, B., M. Gertler, and S. Gilchrist (1996): "The Financial Accelerator and the Flight to Quality," Review of Economics and Statistics, 78(1), 1-15.

Bhagat, S., AND B. BOLTON (2008): "Corporate governance and firm performance," Journal of Corporate Finance, 14(3), 257-273.

BHANDARI, L. C. (1988): "Debt/equity ratio and expected common stock returns: empirical evidence," Journal of Finance, 43(2), 507-528.

Brennan, M., And E. Schwartz (1984): "Optimal Financial Policy and Firm Valuation," Journal of Finance, 39(3), 593-607.

Brown, L. D., AND M. L. CAYlor (2006): "Corporate governance and firm valuation," Journal of Accounting and Public Policy, 25(4), 409-434.

Chaudhry, M., S. Maheshwari, and J. WebB (2004): "REITs and idiosyncratic risk," Journal of Real Estate Research, 26(2), 207-222.

Chen, H., H. WAng, And H. Zhou (2014): "Stock return volatility and capital structure decisions," SSRN Working Paper No. 2346642.

Chen, N., And S. Kou (2009): "Credit spreads, optimal capital structure, and implied volatility with endogenous default and jump risk," Mathematical Finance, 19(3), 343-378.

Cheng, P., And S. E. Roulac (2007): "REIT Characteristics and Predictability," International Real Estate Review, 10(2), 23-41.

Choi, J. (2013): "What Drives the Value Premium? The Role of Asset Risk and Leverage," Review of Financial Studies, 26(11), 2845-2875.

Cremers, K. J. M., AND V. B. NAIR (2005): "Governance Mechanisms and Equity Prices," Journal of Finance, 60(6), 2859-2894.

Cremers, M., And A. Ferrell (2014): "Thirty Years of Shareholder Rights and Firm Value," Journal of Finance, 69(3), 1167-1196.

Cvijanović, D. (2014): "Real Estate Prices and Firm Capital Structure," Review of Financial Studies, 27(9), 2690-2735.

DeAngelo, H., And L. DeAngelo (2007): "Capital structure, payout policy, and financial flexibility," Marshall School of Business Working Paper.

DeAngelo, H., L. DeAngelo, And T. M. Whited (2011): "Capital structure dynamics and transitory debt," Journal of Financial Economics, 99(2), 235-261.

Denis, D. J. (2011): "Financial flexibility and corporate liquidity," Journal of Corporate Finance, 17(3), 667-674, Financial Flexibility and Corporate Liquidity. 
Denis, D. J., And S. B. McKeon (2012): "Debt Financing and Financial Flexibility Evidence from Proactive Leverage Increases," Review of Financial Studies, 25(6), 1897-1929.

Dimitrov, V., AND P. C. JAin (2008): "The Value-Relevance of Changes in Financial Leverage Beyond Growth in Assets and GAAP Earnings," Journal of Accounting, Auditing \& Finance, 23(2), 191-222.

Elliott, R. J., AND J. Shen (2015): "Dynamic optimal capital structure with regime switching," Annals of Finance, 11(2), 199-220.

FAma, E. F. (1980): "Agency Problems and the Theory of the Firm," Journal of Political Economy, 88(2), 288-307.

Fama, E. F., And K. R. French (1992): "The Cross-Section of Expected Stock Returns," Journal of Finance, 47(2), 427-465.

Feng, Z., C. Ghosh, and C. Sirmans (2007): "On the Capital Structure of Real Estate Investment Trusts (REITs)," Journal of Real Estate Finance and Economics, 34(1), 81-105.

Garcia-FeiJóo, L., and R. Jorgensen (2010): "Can operating leverage be the cause of the value premium?," Financial Management, 39(3), 1127-1154.

Garlappi, L., T. Shu, And H. YAn (2008): "Default Risk, Shareholder Advantage, and Stock Returns," Review of Financial Studies, 21(6), 2743-2778.

Garlappi, L., AND H. YAN (2011): "Financial Distress and the Cross-section of Equity Returns," Journal of Finance, 66(3), 789-822.

George, T. J., AND C.-Y. Hwang (2010): "A resolution of the distress risk and leverage puzzles in the cross section of stock returns," Journal of Financial Economics, 96(1), 56-79.

Giacomini, E., D. C. Ling, and A. Naranjo (2015a): "Leverage and Returns: A Cross-Country Analysis of Public Real Estate Markets," Journal of Real Estate Finance and Economics, 51(2), 125-159.

(2015b): "Optimal Capital Structure and the Effects of Deviations from Target Leverage on REIT Return Performance," Working Paper.

Giambona, E., J. Golec, And A. Schwienbacher (2014): "Debt Capacity of Real Estate Collateral," Real Estate Economics, 42(3), 578-605.

Goetzmann, W., J. Ingersoll, M. Spiegel, and I. Welch (2007): "Portfolio Performance Manipulation and Maipulation-Proof Performance Measures," Review of Financial Studies, 20(5), 1503-1546.

Gomes, J. F., And L. Schmid (2010): "Levered Returns," Journal of Finance, 65(2), 467-494.

Gompers, P., J. Ishit, And A. Metrick (2003): "Corporate governance and equity prices," Quarterly Journal of Economics, 118(1), 107-155.

Grossman, S. J., And O. D. Hart (1983): "An Analysis of the Principal-Agent Problem," Econometrica, 51(1), 7-45.

(1986): "The Costs and Benefits of Ownership: A Theory of Vertical and Lateral Integration," Journal of Political Economy, 94(4), 691-719.

Guiso, L., P. SAPienza, And L. Zingales (2015): "The value of corporate culture," Journal of Financial Economics, 117(1), 60-76, \{NBER\} Conference on the Causes and Consequences of Corporate Culture.

Hardin, W. G., M. J. J. Highfield, M. D. Hill, and G. W. Kelly (2009): "The Determinants of REIT Cash Holdings," The Journal of Real Estate Finance and Economics, 39(1), 39-57.

Hardin, W. G., AND M. D. Hill (2008): "REIT dividend determinants: Excess dividends and capital markets," Real Estate Economics, 36(2), 349-369. 
HARris, M., AND A. RAVIV (1988): "Corporate control contests and capital structure," Journal of Financial Economics, 20, 55-86, The Distribution of Power Among Corporate Managers, Shareholders, and Directors.

Harrison, D. M., C. A. Panasian, and M. J. Seiler (2011): "Further Evidence on the Capital Structure of REITs," Real Estate Economics, 39(1), 133-166.

Hart, O., And J. Moore (1990): "Property Rights and the Nature of the Firm," Journal of Political Economy, 98(6), 1119-1158.

Hartzell, J. C., J. G. Kallberg, and C. H. Liu (2008): "The Role of Corporate Governance in Initial Public Offerings: Evidence from Real Estate Investment Trusts," Journal of Law and Economics, 51(3), 539-562.

Hartzell, J. C., L. Sun, And S. Titman (2006): "The Effect of Corporate Governance on Investment: Evidence from Real Estate Investment Trusts," Real Estate Economics, 34(3), 343-376.

Holmström, B., AND J. TIROLE (2011): Inside and Outside Liquidity, vol. 1 of MIT Press Books. MIT Press.

Howe, J. S., And J. D. Shilling (1988): "Capital Structure Theory and REIT Security Offerings," Journal of Finance, 43(4), 983-993.

Hull, R. M. (1999): "Leverage Ratios, Industry Norms, and Stock Price Reaction: An Empirical Investigation of Stock-for-Debt Transactions," Financial Management, 28(2), 32-45.

Jensen, M. C. (1986): "Agency costs of free cash flow, corporate finance, and takeovers," American Economic Review, 76(2), 323-329.

Kiyotaki, N., And J. Moore (1997): "Credit Cycles," Journal of Political Economy, 105(2), 211-48.

Korteweg, A. (2010): "The Net Benefits to Leverage," Journal of Finance, 65(6), $2137-2170$.

Leland, H. E. (1994): "Corporate Debt Value, Bond Covenants, and Optimal Capital Structure," Journal of Finance, 49(4), 1213-52.

Ling, D. C., AND A. NARANJo (2015): "Returns and Information Transmission Dynamics in Public and Private Real Estate Markets," Real Estate Economics, 43(1), 163-208.

Modigliani, F., And M. Miller (1958): "The cost of capital, corporate finance and the theory of investment," American Economic Review, 48(2), 261-297.

Myers, S. (1977): "Determinants of corporate borrowings," Journal of Financial Economics, 5(2), 147-275.

Myers, S., AND N. MAJLuF (1984): "Corporate financing and investment decisions when firms have information that investors do not have," Journal of Financial Economics, 13(2), 187-221.

Novaes, W., AND L. Zingales (1995): "Capital Structure Choice when Managers are in Control: Entrenchment versus Efficiency," Working Paper 5384, National Bureau of Economic Research.

Obreja, I. (2013): "Book-to-Market Equity, Financial Leverage, and the CrossSection of Stock Returns," Review of Financial Studies, Forthcoming.

Otт, S. H., T. J. Riddiough, AND H.-C. Yi (2005): "Finance, Investment and Investment Performance: Evidence from the REIT Sector," Real Estate Economics, 33(1), 203-235.

Pavlov, A., E. Steiner, And S. Wachter (2015): "Macroeconomic Risk Factors and the Role of Mispriced Credit in the Returns from International Real Estate Securities," Real Estate Economics, 43(1), 241-270.

Penman, S., S. A. Richardson, And I. Tuna (2007): "The Book-to-Price Effect 
in Stock Returns: Accounting for Leverage," Journal of Accounting Research, $45(2), 427-467$.

Perez-Quiros, G., And A. Timmermann (2000): "Firm Size and Cyclical Variations in Stock Returns," Journal of Finance, 55(3), 1229-1262.

Riddiough, T. J., AND Z. Wu (2009): "Financial Constraints, Liquidity Management and Investment," Real Estate Economics, 37(3), 447-481.

Scott, James H., J. (1976): "A Theory of Optimal Capital Structure," The Bell Journal of Economics, 7(1), 33-54.

Shilling, J. D. (1994): "Taxes and the Capital Structure of Partnerships, REITs, and Other Related Entities," Working Paper 94-16, Wisconsin-Madison CULER.

Steri, R., F. Ippolito, and C. Tebaldi (2012): "The Relative Leverage Premium," in Midwest Finance Association 2012 Annual Meetings Paper.

Stulz, R. M. (1988): "The Distribution of Power Among Corporate Managers, Shareholders, and Directors Managerial control of voting rights," Journal of Financial Economics, 20, 25-54.

Sun, L., S. D. Titman, And G. J. Twite (2015): "REIT and Commercial Real Estate Returns: A Postmortem of the Financial Crisis," Real Estate Economics, $43(1), 8-36$.

Sun, Q., AND K. Yung (2009): "Idiosyncratic Risk and Expected Returns of Equity Real Estate Investment Trusts," Journal of Real Estate Portfolio Management, $15(1), 45-57$. 


\section{$9 \quad$ Figures and Tables}

SNL governance score and REIT price/NAV ratios

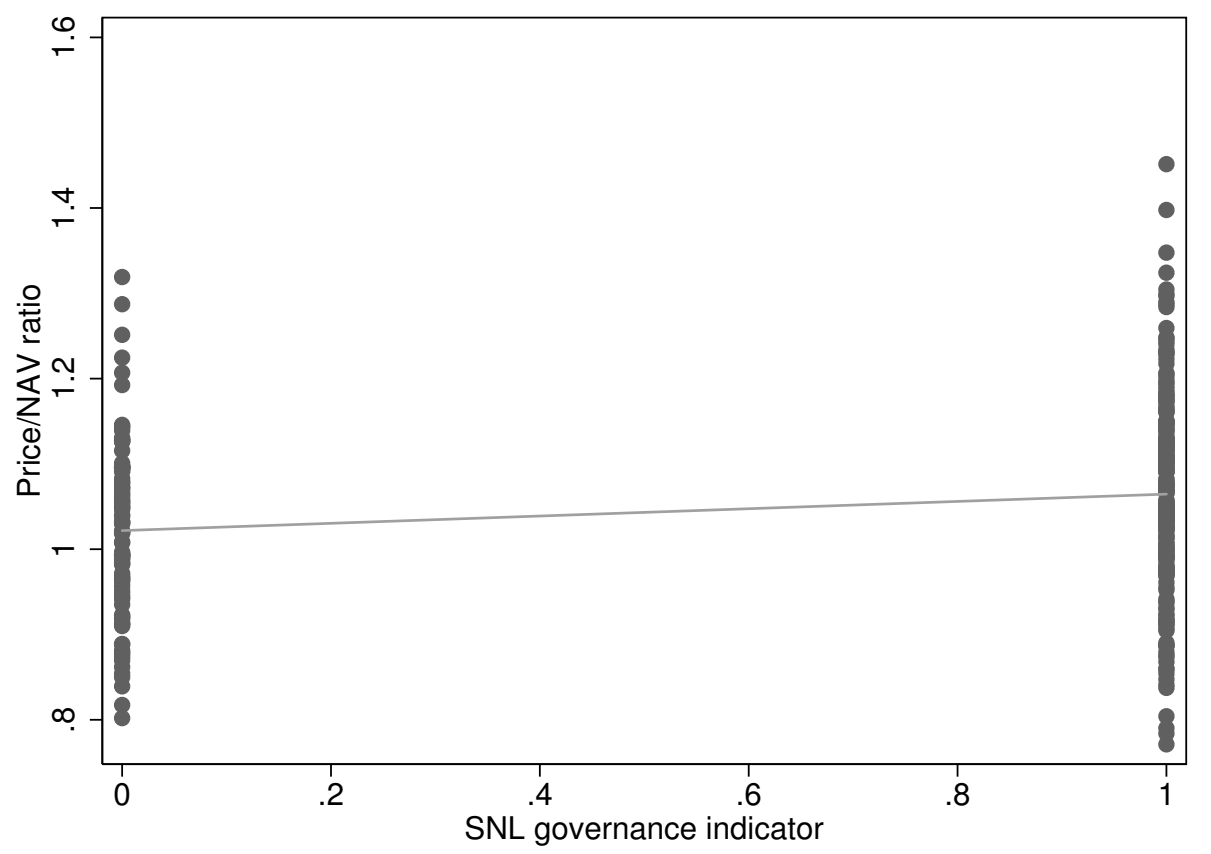

Fig. 1. The figure shows a scatter plot between the indicator variable of good (i.e. shareholder-friendly) corporate governance and REIT discount/premia to NAV for the sample firms in 2006. The scatter plot also shows a fitted line from an OLS regression of the price/NAV ratio of the sample REITs on the SNL governance indicator, suggesting that firms with stronger corporate governance (SNL governance indicator=1) achieved a higher market valuation of equity relative to the value of underlying assets. 
Scatter plots of cumulative total return 2007-2009 as a function of capital structure choices US REITs

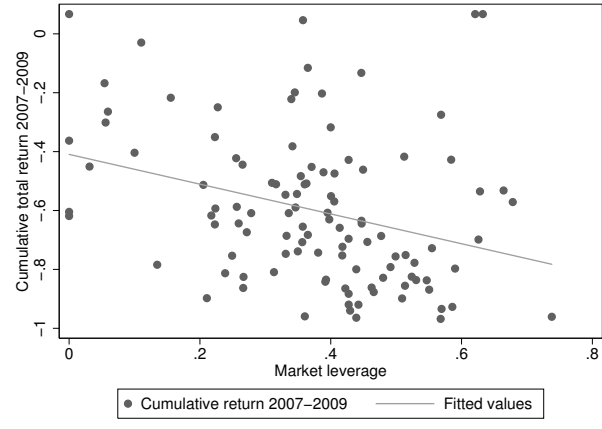

(a) Market leverage, US

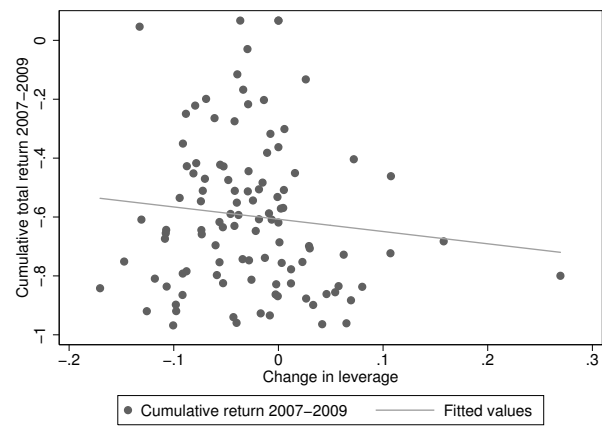

(c) Change in market leverage, US

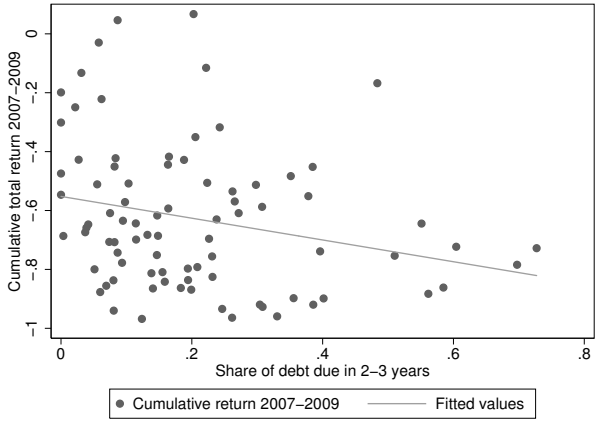

(b) Share of debt due in 2-3 years, US

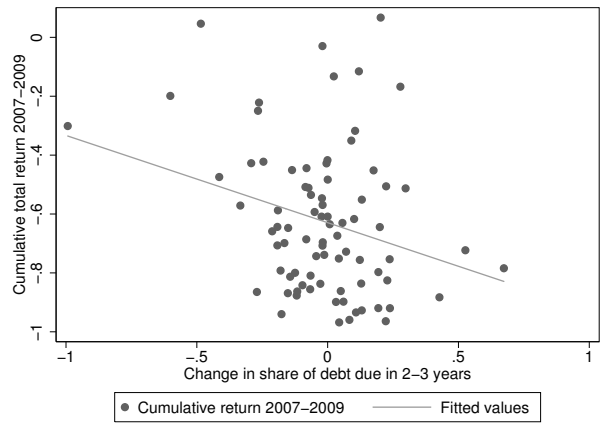

(d) Change in debt due in 2-3 years, US

Fig. 2. The figure shows scatter plots for the cumulative total return on US REITs during the period 2007-2009 as a function of capital structure choices. Variables are defined as in Table 1. 
Scatter plots of cumulative total return 2007-2009 as a function of capital structure choices European REITs

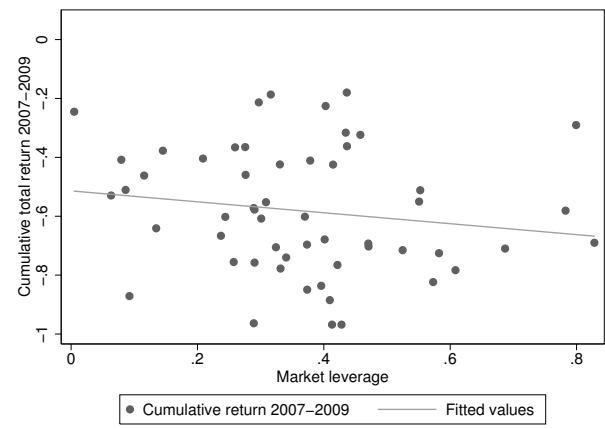

(a) Market leverage, Europe

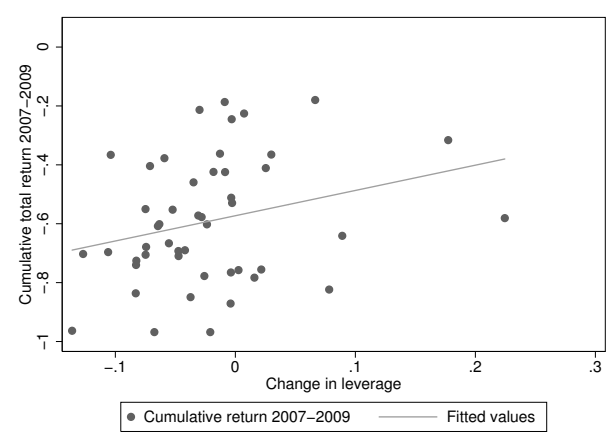

(c) Change in market leverage, Europe

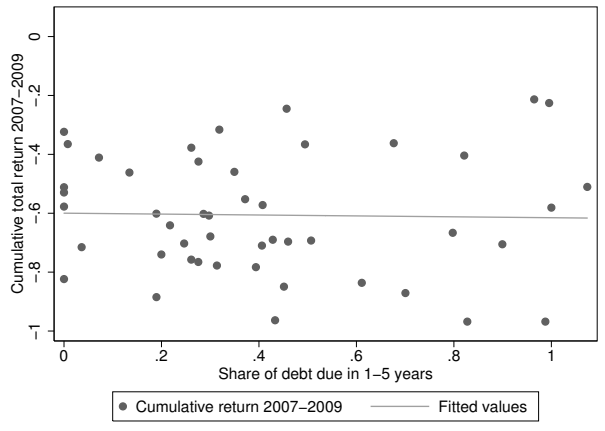

(b) Share of debt due in 1-5 years, Europe

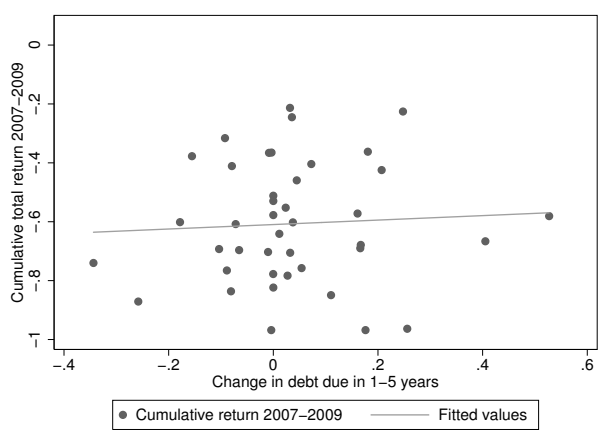

(d) Change in share of debt due in 1-5 years, Europe

Fig. 3. The figure shows scatter plots for the cumulative total return on the European REITs during the period 2007-2009 as a function of capital structure choices. Variables are defined as in Table 1. 
Descriptive statistics for listed equity REITs, 2006

\begin{tabular}{|c|c|c|c|c|c|c|c|c|}
\hline US & & & & & & & & \\
\hline Variable & $\mathrm{N}$ & Mean & $\mathrm{SD}$ & P5 & $\mathrm{P} 25$ & Median & P75 & P95 \\
\hline Change in leverage & 126 & -0.02 & 0.07 & -0.11 & -0.06 & -0.03 & 0.00 & 0.08 \\
\hline Change debt due in $2-3$ years & 99 & -0.02 & 0.24 & -0.41 & -0.12 & -0.02 & 0.11 & 0.30 \\
\hline Market leverage & 130 & 0.39 & 0.16 & 0.05 & 0.31 & 0.39 & 0.49 & 0.63 \\
\hline Share of debt due in $2-3$ years & 104 & 0.20 & 0.17 & 0.00 & 0.07 & 0.16 & 0.30 & 0.56 \\
\hline SNL governance score & 136 & 0.34 & 0.53 & 0.00 & 0.00 & 0.00 & 1.00 & 1.00 \\
\hline Log of firm size & 132 & 14.20 & 1.54 & 10.90 & 13.65 & 14.39 & 15.15 & 16.40 \\
\hline Tobin's q & 130 & 1.55 & 0.46 & 1.11 & 1.24 & 1.48 & 1.66 & 2.32 \\
\hline Cash to assets & 132 & 0.03 & 0.05 & 0.00 & 0.00 & 0.01 & 0.03 & 0.12 \\
\hline Cumulative total return 2007-2009 & 113 & -0.59 & 0.26 & -0.93 & -0.80 & -0.62 & -0.43 & -0.12 \\
\hline \multicolumn{9}{|l|}{ Europe } \\
\hline Variable & $\mathrm{N}$ & Mean & $\mathrm{SD}$ & P5 & $\mathrm{P} 25$ & Median & P75 & P95 \\
\hline Change in leverage & 52 & -0.02 & 0.07 & -0.11 & -0.07 & -0.03 & 0.00 & 0.15 \\
\hline Change in debt due in $1-5$ years & 43 & 0.04 & 0.16 & -0.18 & -0.07 & 0.02 & 0.16 & 0.34 \\
\hline Market leverage & 59 & 0.35 & 0.19 & 0.00 & 0.26 & 0.33 & 0.44 & 0.78 \\
\hline Share of debt due in $1-5$ years & 49 & 0.42 & 0.31 & 0.00 & 0.22 & 0.37 & 0.61 & 1.00 \\
\hline SNL governance score & 68 & 0.59 & 0.50 & 0.00 & 0.00 & 1.00 & 1.00 & 1.00 \\
\hline Log of firm size & 60 & 13.98 & 1.37 & 12.03 & 13.10 & 13.92 & 14.89 & 16.23 \\
\hline Tobin's q & 59 & 1.15 & 0.30 & 0.75 & 1.03 & 1.12 & 1.20 & 1.68 \\
\hline Cash to assets & 59 & 0.03 & 0.04 & 0.00 & 0.01 & 0.02 & 0.04 & 0.15 \\
\hline Cumulative total return $2007-2009$ & 63 & -0.56 & 0.23 & -0.88 & -0.72 & -0.58 & -0.37 & -0.19 \\
\hline
\end{tabular}

Table 1

The table shows the summary statistics for the sample firms, all US and European listed equity REITs on $S N L$, at the end of 2006. Variables are defined as outlined below. We measure the change in leverage over the year 2006 as the first difference of market leverage. Market leverage is defined as the ratio of total debt (book value of short-term and long-term interest bearing debt) to market value of invested capital. Market value of invested capital is defined as the sum of total debt, preferred stock and market capitalisation, calculated as number of shares outstanding multiplied by the end-of-period share price. For US REITs, we measure the change in debt maturity as the first difference of the share of debt due in 2-3 years. For European REITs, we have to measure the change in debt maturity as the first difference of the share of debt due in 1-5 years, as European REITs do not report a year-by-year debt schedule. The control variables considered in our study are the level of leverage and the share of debt due in 2-3 years, further the log of firm size (measured as market capitalisation), Tobin's q (ratio of firm market value, i.e. market capitalisation plus total assets less book value of equity, to total assets), and the cash-to-assets ratio (cash and cash equivalents to total assets). We obtain information on the firm's corporate governance provisions from $S N L$. The provisions covered by $S N L$ are staggered board, poison pill, and supermajority requirements. The presence of these provisions restricts shareholder rights. We calculate a governance score by starting from zero and adding a point for the presence of each provision. 


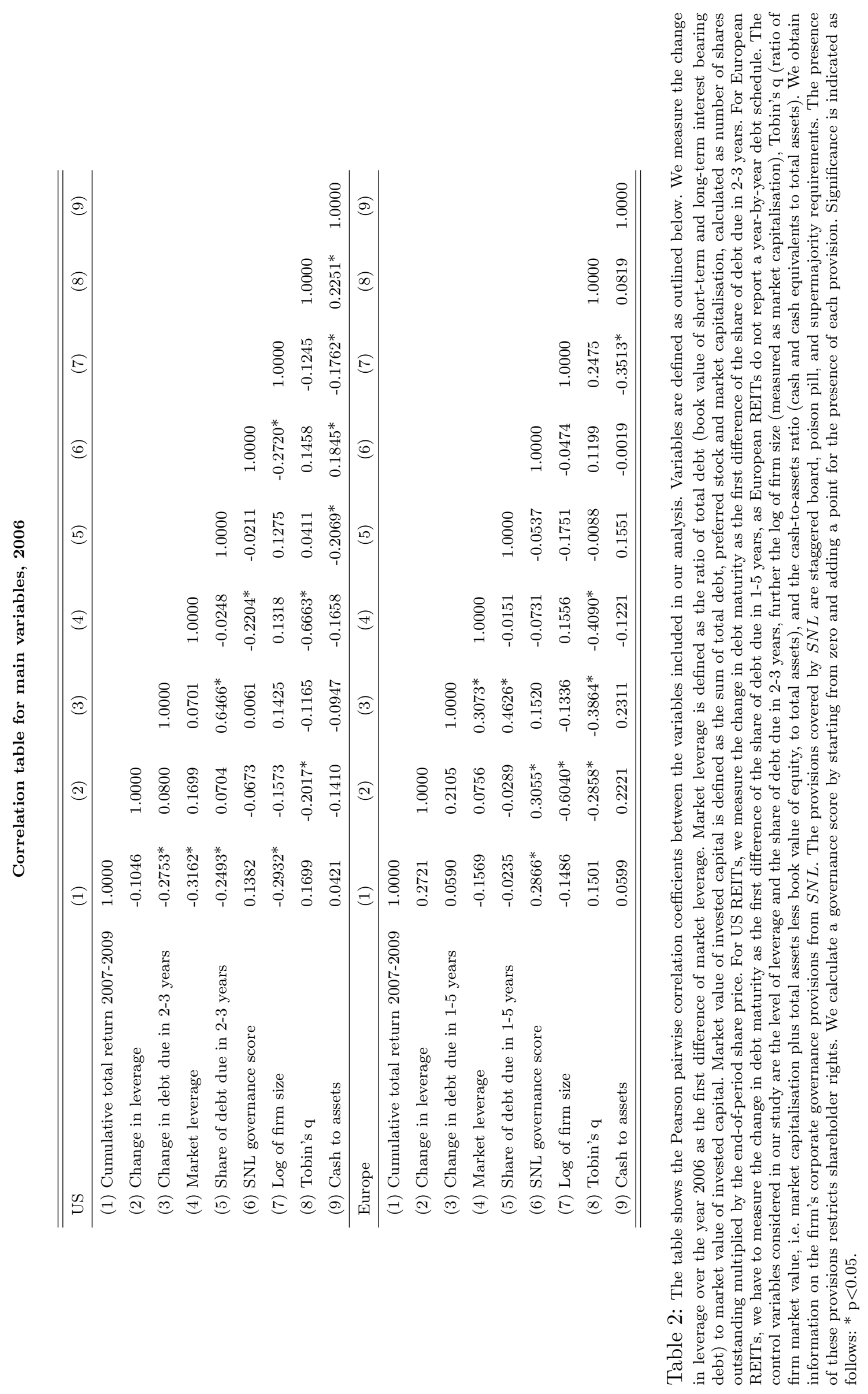


Firm characteristics sorted by leverage ratio quintiles in 2006

\begin{tabular}{lccccccc}
\hline \hline US firms - Quintile & 1 & 2 & 3 & 4 & 5 & Difference & (t-stat) \\
\hline Market leverage & 0.146 & 0.327 & 0.395 & 0.468 & 0.603 & $0.457^{* * *}$ & $(20.32)$ \\
Share of debt due in 2-3 years & 0.216 & 0.155 & 0.224 & 0.240 & 0.169 & -0.047 & $(-0.83)$ \\
Change in leverage & -0.035 & -0.051 & -0.018 & -0.003 & -0.002 & $0.0332^{*}$ & $(2.03)$ \\
Change in debt due in 2-3 years & -0.036 & -0.075 & 0.011 & 0.046 & -0.012 & 0.024 & $(0.29)$ \\
SNL governance score & 0.654 & 0.231 & 0.308 & 0.192 & 0.308 & -0.346 & $(-2.00)$ \\
Log of firm size & 13.496 & 14.877 & 14.572 & 14.331 & 13.748 & 0.252 & $(0.50)$ \\
Tobin's Q & 2.043 & 1.702 & 1.463 & 1.312 & 1.218 & $-0.825^{* * *}$ & $(-6.40)$ \\
Cash to assets & 0.044 & 0.037 & 0.019 & 0.024 & 0.022 & -0.022 & $(-1.63)$ \\
Cumulative total return 2007-2009 & -0.468 & -0.574 & -0.577 & -0.752 & -0.641 & -0.173 & $(-1.97)$ \\
& & & & & & & \\
\hline European firms - Quintile & 1 & 2 & 3 & 4 & 5 & Difference & $(\mathrm{t}$-stat) \\
\hline Market leverage & 0.090 & 0.273 & 0.345 & 0.427 & 0.633 & $0.543^{* * *}$ & $(13.43)$ \\
Share of debt due in 1-5 years & 0.458 & 0.410 & 0.387 & 0.487 & 0.314 & -0.144 & $(-0.81)$ \\
Change in leverage & 0.011 & -0.039 & -0.049 & 0.002 & -0.006 & -0.018 & $(-0.42)$ \\
Change in debt due in 1-5 years & -0.049 & 0.096 & -0.065 & 0.077 & 0.118 & 0.167 & $(1.66)$ \\
SNL governance score & 0.583 & 0.500 & 0.583 & 0.833 & 0.273 & -0.311 & $(-1.51)$ \\
Log of firm size & 13.037 & 14.277 & 14.515 & 14.050 & 14.111 & 1.075 & $(1.71)$ \\
Tobin's Q & 1.290 & 1.189 & 1.195 & 1.098 & 0.953 & -0.338 & $(-2.01)$ \\
Cash to assets & 0.062 & 0.028 & 0.015 & 0.023 & 0.035 & -0.027 & $(-1.13)$ \\
Cumulative total return 2007-2009 & -0.494 & -0.573 & -0.616 & -0.566 & -0.644 & -0.150 & $(-2.03)$ \\
\hline \hline
\end{tabular}

Table 3

The table presents the firm characteristics of the US and European equity REITs in our sample in 2006 by leverage ratio quintile. All variables are defined as in Table 1. The Table also shows the spread (Difference) between the mean variable values across the 5 th (highest) and 1st (lowest) leverage ratio quintile alongside the corresponding t-statistic from a two-group mean-comparison test. Significance is indicated as follows: * $p<0.1,{ }^{* *} p<0.05,{ }^{* * *} p<0.01$. 
Capital structure choices in 2006 sorted by cumulative total return quintiles 2007-2009

\begin{tabular}{lccccccc}
\hline \hline US firms - Quintile & 1 & 2 & 3 & 4 & 5 & Difference & (t-stat) \\
\hline Cumulative total return 2007-2009 & -0.893 & -0.757 & -0.622 & -0.469 & -0.173 & $0.720^{* * *}$ & $(23.85)$ \\
Market leverage & 0.467 & 0.417 & 0.321 & 0.348 & 0.297 & $-0.169^{* *}$ & $(-3.47)$ \\
Share of debt due in 2-3 years & 0.251 & 0.249 & 0.183 & 0.159 & 0.135 & $-0.117^{*}$ & $(-2.14)$ \\
Change in leverage & -0.019 & -0.011 & -0.036 & -0.030 & -0.040 & -0.021 & $(-1.11)$ \\
Change in debt due in 2-3 years & 0.035 & 0.063 & -0.045 & -0.048 & -0.151 & -0.185 & $(-1.90)$ \\
& & & & & & & \\
\hline European firms - Quintile & 1 & 2 & 3 & 4 & 5 & Difference & $($ t-stat $)$ \\
\hline Cumulative total return 2007-2009 & -0.846 & -0.700 & -0.577 & -0.411 & -0.221 & $0.626^{* * *}$ & $(16.42)$ \\
Market leverage & 0.376 & 0.476 & 0.353 & 0.251 & 0.394 & 0.018 & $(0.23)$ \\
Share of debt due in 1-5 years & 0.454 & 0.428 & 0.277 & 0.417 & 0.547 & 0.093 & $(0.53)$ \\
Change in leverage & -0.022 & -0.074 & -0.003 & -0.028 & 0.035 & 0.057 & $(1.80)$ \\
Change in debt due in 1-5 years & 0.017 & 0.031 & 0.051 & 0.032 & 0.056 & 0.038 & $(0.47)$ \\
\hline \hline
\end{tabular}

Table 4

The table presents the capital structure choices of the US and European equity REITs in our sample in 2006 by quintiles of the cumulative total return 2007-2009. All variables are defined as in Table 1 . The Table also shows the spread (Difference) between the mean variable values across the 5th (highest) and 1st (lowest) leverage ratio quintile alongside the corresponding t-statistic from a two-group mean-comparison test. Significance is indicated as follows: ${ }^{*} p<0.1,{ }^{* *} p<0.05,{ }^{* * *} p<0.01$. 
Regression results for cumulative total return, 2007-2009

\begin{tabular}{|c|c|c|c|c|}
\hline Dependent variable: Cumulative total return 2007-2009 & $(1)$ & $(2)$ & $(3)$ & $(4)$ \\
\hline VARIABLES & US & US & Europe & Europe \\
\hline \multirow[t]{2}{*}{ Change in leverage } & $-0.783^{* *}$ & & $1.296 * *$ & \\
\hline & $(-2.06)$ & & $(2.11)$ & \\
\hline \multirow[t]{2}{*}{ Change in debt due in $2-3$ years } & & $-0.333^{* * *}$ & & \\
\hline & & $(-2.90)$ & & \\
\hline \multirow[t]{2}{*}{ Change in debt due in $1-5$ years } & & & & 0.347 \\
\hline & & & & $(1.39)$ \\
\hline \multirow[t]{2}{*}{ Market leverage } & $-0.455^{* *}$ & & -0.194 & \\
\hline & $(-2.31)$ & & $(-0.89)$ & \\
\hline \multirow[t]{2}{*}{ Log of firm size } & $-0.055^{* * *}$ & $-0.056^{* *}$ & 0.006 & $-0.048^{*}$ \\
\hline & $(-2.95)$ & $(-2.06)$ & $(0.16)$ & $(-1.95)$ \\
\hline \multirow[t]{2}{*}{ Tobin's q } & -0.062 & $0.125^{* *}$ & 0.153 & $0.261^{* * *}$ \\
\hline & $(-0.99)$ & $(2.29)$ & $(1.58)$ & $(2.81)$ \\
\hline \multirow[t]{2}{*}{ Cash to assets } & -0.206 & 0.141 & -0.461 & -0.912 \\
\hline & $(-0.58)$ & $(0.57)$ & $(-0.61)$ & $(-1.01)$ \\
\hline \multirow[t]{2}{*}{ Constant } & $0.686^{* *}$ & 0.337 & $-0.892^{*}$ & -0.372 \\
\hline & $(2.44)$ & $(0.91)$ & $(-1.96)$ & $(-1.13)$ \\
\hline Observations & 106 & 81 & 47 & 40 \\
\hline R-squared & 0.367 & 0.431 & 0.209 & 0.194 \\
\hline Sector effects & Yes & Yes & Yes & Yes \\
\hline
\end{tabular}

Table 5

The table shows the results of the OLS model estimated for the sample firms, the listed equity REITs on $S N L$ in the US and in Europe. The dependent variable is the cumulative total return over the period $2007 / 2009$. All independent variables are measured at the end of 2006, with the exception of the variables measuring the changes in capital structure, which are measured during the year 2006. Variables are defined as follows. We measure the change in leverage over the year 2006 as the first difference of market leverage. Market leverage is defined as the ratio of total debt (book value of short-term and long-term interest bearing debt) to market value of invested capital. Market value of invested capital is defined as the sum of total debt, preferred stock and market capitalisation, calculated as number of shares outstanding multiplied by the end-of-period share price. For US REITs, we measure the change in debt maturity as the first difference of the share of debt due in 2-3 years. For European REITs, we have to measure the change in debt maturity as the first difference of the share of debt due in 1-5 years, as European REITs do not report a year-by-year debt schedule. The control variables considered in our study are the level of leverage and the share of debt due in 2-3 years, further the log of firm size (measured as market capitalisation), Tobin's q (ratio of firm market value, i.e. market capitalisation plus total assets less book value of equity, to total assets), and the cash-to-assets ratio (cash and cash equivalents to total assets). We account for property sector effects using indicator variables. The t-statistics, calculated using heteroskedasticity-robust standard errors, are shown in parentheses. Significance is indicated as follows: *** $\mathrm{p}<0.01,{ }^{*} * \mathrm{p}<0.05, * \mathrm{p}<0.10$. 
Regression results for likelihood to reduce leverage or extend debt maturity, 2006

\begin{tabular}{|c|c|c|c|c|}
\hline \multirow[t]{2}{*}{ REGION } & \multicolumn{2}{|c|}{ US } & \multicolumn{2}{|c|}{ Europe } \\
\hline & (1) & $(2)$ & $(3)$ & $(4)$ \\
\hline VARIABLES & Leverage & Maturity & Leverage & Maturity \\
\hline \multirow[t]{2}{*}{ Market leverage } & $6.230^{* * *}$ & & 4.216 & \\
\hline & $(2.82)$ & & $(1.51)$ & \\
\hline \multirow[t]{2}{*}{ Share of debt due in $2-3$ years } & & $10.022^{* * *}$ & & \\
\hline & & $(3.85)$ & & \\
\hline \multirow[t]{2}{*}{ Share of debt due in $1-5$ years } & & & & 1.662 \\
\hline & & & & $(1.10)$ \\
\hline \multirow[t]{2}{*}{ Log of firm size } & 0.225 & $-0.415^{*}$ & $0.867^{* *}$ & -0.293 \\
\hline & $(1.37)$ & $(-1.81)$ & $(2.46)$ & $(-0.86)$ \\
\hline \multirow[t]{2}{*}{ Tobin's q } & 1.491 & 0.101 & 2.59 & 3.195 \\
\hline & $(1.33)$ & $(0.09)$ & $(0.99)$ & $(1.61)$ \\
\hline \multirow[t]{2}{*}{ Cash to assets } & 5.654 & -0.649 & 5.052 & -8.08 \\
\hline & $(1.12)$ & $(-0.11)$ & $(0.77)$ & $(-0.84)$ \\
\hline \multirow[t]{2}{*}{ Constant } & $-9.941^{* * *}$ & 4.126 & $-17.390^{* * *}$ & -1.019 \\
\hline & $(-3.07)$ & $(1.41)$ & $(-2.72)$ & $(-0.22)$ \\
\hline Observations & 126 & 90 & 48 & 41 \\
\hline Sector effects & Yes & Yes & Yes & Yes \\
\hline Pseudo-R squared & 0.127 & 0.260 & 0.278 & 0.162 \\
\hline
\end{tabular}

Table 6

The table shows the results of the logit model estimated for the sample firms, the listed equity REITs on $S N L$ in the US (columns (1) and (2)) and in Europe (columns (3) and (4)). The dependent variable is the likelihood to reduce leverage (columns (1) and (3)) or extend debt maturity (columns (2) and (4)) by 0.05 or more during 2006. Independent variables are lagged by one year, i.e. they are measured at the end of 2005. Variables are defined as follows. Market leverage is defined as the ratio of total debt (book value of short-term and long-term interest bearing debt) to market value of invested capital. Market value of invested capital is defined as the sum of total debt, preferred stock and market capitalisation, calculated as number of shares outstanding multiplied by the end-of-period share price. For US REITs, we measure debt maturity as the share of debt due in 2-3 years. For European REITs, we have to measure debt maturity as the share of debt due in 1-5 years, as European REITs do not report a year-by-year debt schedule. The control variables considered in our study are the level of leverage and the share of debt due in 2-3 years, further the log of firm size (measured as market capitalisation), Tobin's q (ratio of firm market value, i.e. market capitalisation plus total assets less book value of equity, to total assets), and the cash-to-assets ratio (cash and cash equivalents to total assets). We account for property sector effects using indicator variables. The z-statistics are shown in parentheses. Significance is indicated as follows: ${ }^{* * *} \mathrm{p}<0.01,{ }^{* *} \mathrm{p}<0.05,{ }^{*} \mathrm{p}<0.10$. 
Regression results for likelihood to reduce leverage or extend debt maturity as a function of corporate governance, 2006

\begin{tabular}{|c|c|c|c|c|}
\hline \multirow[t]{2}{*}{ REGION } & \multicolumn{2}{|c|}{ US } & \multicolumn{2}{|c|}{ Europe } \\
\hline & (1) & (2) & (3) & (4) \\
\hline VARIABLES & Leverage & Maturity & Leverage & Maturity \\
\hline \multirow[t]{2}{*}{ High leverage $*$ Strong governance } & $1.217^{*}$ & & -0.155 & \\
\hline & $(1.88)$ & & $(-0.10)$ & \\
\hline \multirow[t]{2}{*}{ Short maturity * Strong governance } & & 0.460 & & 29.597 \\
\hline & & $(0.52)$ & & $(0.01)$ \\
\hline \multirow[t]{2}{*}{ Market leverage } & $4.510^{*}$ & & 4.18 & \\
\hline & $(1.92)$ & & $(1.18)$ & \\
\hline \multirow[t]{2}{*}{ Share of debt due in $2-3$ years } & & $9.262^{* * *}$ & & \\
\hline & & $(3.17)$ & & \\
\hline \multirow[t]{2}{*}{ Share of debt due in $1-5$ years } & & & & 0.837 \\
\hline & & & & $(0.48)$ \\
\hline \multirow[t]{2}{*}{ SNL governance score } & 0.291 & 0.403 & -1.216 & 29.602 \\
\hline & $(0.51)$ & $(0.50)$ & $(-1.06)$ & $(0.01)$ \\
\hline \multirow[t]{2}{*}{ Log of firm size } & 0.185 & $-0.406^{*}$ & $0.919^{* *}$ & -0.287 \\
\hline & $(1.11)$ & $(-1.77)$ & $(2.49)$ & $(-0.83)$ \\
\hline \multirow[t]{2}{*}{ Tobin's q } & 1.87 & -0.065 & 3.492 & 2.704 \\
\hline & $(1.63)$ & $(-0.06)$ & $(1.15)$ & $(1.38)$ \\
\hline \multirow[t]{2}{*}{ Cash to assets } & 5.87 & -0.791 & 6.739 & -8.473 \\
\hline & $(1.18)$ & $(-0.14)$ & $(0.97)$ & $(-0.90)$ \\
\hline \multirow[t]{2}{*}{ Constant } & $-9.799 * * *$ & 4.095 & $-18.380^{* * *}$ & -29.726 \\
\hline & $(-2.93)$ & (1.39) & $(-2.60)$ & $(-0.01)$ \\
\hline Observations & 126 & 90 & 48 & 41 \\
\hline Sector effects & Yes & Yes & Yes & Yes \\
\hline Pseudo-R squared & 0.153 & 0.298 & 0.308 & 0.202 \\
\hline
\end{tabular}

Table 7

The table shows the results of the logit model estimated for the sample firms, the listed equity REITs on $S N L$ in the US (columns (1) and (2)) and in Europe (columns (3) and (4)). In the US sample, we focus on the interaction between high (above-median) leverage (column (1)) or below-median shares of debt maturing in 2-3 years (column (2)). The dependent variable is the likelihood to reduce leverage (columns (1) and (3)) or extend debt maturity (columns (2) and (4)) by 0.05 or more in 2006. Independent variables are lagged by one year, i.e. they are measured at the end of 2005. For Europe, the analysis is analogous to the US, only we replace the debt maturity variable with the above-median share of debt maturing in 1-5 years. Variables are defined as follows. We obtain information on the firm's corporate governance provisions from $S N L$. The provisions covered by $S N L$ are staggered board, poison pill, and supermajority requirements. The presence of these provisions restricts shareholder rights. We calculate a governance score by starting from zero and adding a point for the presence of each provision. Market leverage is defined as the ratio of total debt (book value of short-term and long-term interest bearing debt) to market value of invested capital. Market value of invested capital is defined as the sum of total debt, preferred stock and market capitalisation, calculated as number of shares outstanding multiplied by the end-of-period share price. For US REITs, we measure debt maturity as the share of debt due in 2-3 years. For European REITs, we have to measure debt maturity as the share of debt due in 1-5 years, as European REITs do not report a year-by-year debt schedule. The control variables considered in our study are the level of leverage and the share of debt due in 2-3 years, further the $\log$ of firm size (measured as market capitalisation), Tobin's q (ratio of firm market value, i.e. market capitalisation plus total assets less book value of equity, to total assets), and the cash-to-assets ratio (cash and cash equivalents to total assets). We account for property sector effects using indicator variables. The z-statistics are shown in parentheses. Significance is indicated as follows: $* * * p<0.01,{ }^{* *} \mathrm{p}<0.05,^{*}$ $\mathrm{p}<0.10$. 


\section{Appendices}

\section{A Descriptive statistics by property type for the US firms}

\begin{tabular}{|c|c|c|c|c|c|c|c|c|}
\hline Variable & $\mathrm{N}$ & Mean & $\mathrm{SD}$ & P5 & P25 & Median & P75 & P95 \\
\hline \multicolumn{9}{|l|}{ Diversified } \\
\hline Change in leverage & 16 & 0.010 & 0.090 & -0.150 & -0.040 & 0.000 & 0.050 & 0.270 \\
\hline Change in debt due in $2-3$ years & 11 & -0.090 & 0.170 & -0.410 & -0.140 & -0.080 & 0.030 & 0.190 \\
\hline Market leverage & 17 & 0.430 & 0.200 & 0.000 & 0.350 & 0.440 & 0.570 & 0.740 \\
\hline Share of debt due in 2-3 years & 11 & 0.090 & 0.060 & 0.000 & 0.050 & 0.080 & 0.150 & 0.190 \\
\hline SNL governance score & 17 & 0.410 & 0.620 & 0.000 & 0.000 & 0.000 & 1.000 & 2.000 \\
\hline Log of firm size & 17 & 13.620 & 1.940 & 10.340 & 12.660 & 14.190 & 14.870 & 16.700 \\
\hline Tobin's Q & 17 & 1.460 & 0.520 & 0.940 & 1.120 & 1.160 & 1.700 & 2.840 \\
\hline Cash to assets & 17 & 0.080 & 0.100 & 0.010 & 0.010 & 0.050 & 0.110 & 0.430 \\
\hline Cumulative total return 2007-2009 & 16 & -0.640 & 0.240 & -0.960 & -0.810 & -0.650 & -0.530 & 0.070 \\
\hline \multicolumn{9}{|l|}{ Health care } \\
\hline Change in leverage & 11 & 0.000 & 0.070 & -0.090 & -0.040 & -0.020 & -0.010 & 0.160 \\
\hline Change in debt due in $2-3$ years & 6 & 0.120 & 0.120 & -0.020 & 0.000 & 0.100 & 0.220 & 0.280 \\
\hline Market leverage & 11 & 0.250 & 0.150 & 0.040 & 0.060 & 0.310 & 0.360 & 0.450 \\
\hline Share of debt due in $2-3$ years & 7 & 0.190 & 0.160 & 0.000 & 0.060 & 0.210 & 0.220 & 0.480 \\
\hline SNL governance score & 12 & 0.500 & 0.520 & 0.000 & 0.000 & 0.500 & 1.000 & 1.000 \\
\hline Log of firm size & 11 & 13.920 & 1.280 & 11.850 & 13.250 & 13.980 & 15.000 & 16.120 \\
\hline Tobin's Q & 11 & 1.720 & 0.360 & 1.350 & 1.430 & 1.610 & 1.900 & 2.520 \\
\hline Cash to assets & 11 & 0.040 & 0.080 & 0.000 & 0.000 & 0.010 & 0.050 & 0.270 \\
\hline Cumulative total return 2007-2009 & 11 & -0.310 & 0.190 & -0.680 & -0.460 & -0.280 & -0.170 & -0.030 \\
\hline \multicolumn{9}{|l|}{ Hotel } \\
\hline Change in leverage & 18 & -0.020 & 0.070 & -0.170 & -0.090 & -0.020 & 0.010 & 0.130 \\
\hline Change in debt due in $2-3$ years & 17 & 0.050 & 0.160 & -0.150 & -0.100 & 0.050 & 0.190 & 0.400 \\
\hline Market leverage & 18 & 0.410 & 0.100 & 0.220 & 0.330 & 0.400 & 0.470 & 0.630 \\
\hline Share of debt due in $2-3$ years & 18 & 0.220 & 0.160 & 0.040 & 0.090 & 0.190 & 0.260 & 0.580 \\
\hline SNL governance score & 18 & 0.390 & 0.500 & 0.000 & 0.000 & 0.000 & 1.000 & 1.000 \\
\hline Log of firm size & 18 & 13.930 & 1.400 & 10.370 & 13.200 & 14.250 & 14.780 & 16.280 \\
\hline Tobin's Q & 18 & 1.320 & 0.140 & 1.160 & 1.190 & 1.280 & 1.440 & 1.650 \\
\hline Cash to assets & 18 & 0.030 & 0.030 & 0.000 & 0.010 & 0.010 & 0.030 & 0.140 \\
\hline Cumulative total return 2007-2009 & 13 & -0.760 & 0.260 & -0.960 & -0.860 & -0.840 & -0.780 & 0.070 \\
\hline
\end{tabular}

Table A.1

The table presents the descriptive statistics for the US sample firms by property sector. Variables are defined as in Table 1. 


\begin{tabular}{|c|c|c|c|c|c|c|c|c|}
\hline Variable & $\mathrm{N}$ & Mean & $\mathrm{SD}$ & P5 & P25 & Median & P75 & P95 \\
\hline \multicolumn{9}{|l|}{ Office } \\
\hline Change in leverage & 27 & -0.030 & 0.050 & -0.100 & -0.070 & -0.040 & 0.000 & 0.080 \\
\hline Change in debt due in $2-3$ years & 23 & 0.030 & 0.230 & -0.250 & -0.180 & 0.010 & 0.120 & 0.530 \\
\hline Market leverage & 29 & 0.390 & 0.160 & 0.000 & 0.350 & 0.410 & 0.490 & 0.620 \\
\hline Share of debt due in 2-3 years & 25 & 0.220 & 0.210 & 0.000 & 0.040 & 0.110 & 0.380 & 0.600 \\
\hline SNL governance score & 30 & 0.200 & 0.410 & 0.000 & 0.000 & 0.000 & 0.000 & 1.000 \\
\hline Log of firm size & 30 & 14.540 & 1.610 & 11.240 & 13.840 & 14.920 & 15.350 & 16.580 \\
\hline Tobin's Q & 29 & 1.570 & 0.670 & 1.110 & 1.220 & 1.430 & 1.590 & 2.170 \\
\hline Cash to assets & 30 & 0.020 & 0.030 & 0.000 & 0.000 & 0.010 & 0.030 & 0.070 \\
\hline Cumulative total return 2007-2009 & 23 & -0.650 & 0.200 & -0.940 & -0.760 & -0.690 & -0.470 & -0.360 \\
\hline \multicolumn{9}{|l|}{ Residential } \\
\hline Change in leverage & 17 & -0.040 & 0.040 & -0.110 & -0.060 & -0.040 & -0.020 & 0.070 \\
\hline Change in debt due in $2-3$ years & 8 & -0.070 & 0.070 & -0.190 & -0.110 & -0.050 & -0.010 & 0.000 \\
\hline Market leverage & 17 & 0.450 & 0.140 & 0.220 & 0.330 & 0.430 & 0.570 & 0.660 \\
\hline Share of debt due in $2-3$ years & 8 & 0.190 & 0.080 & 0.060 & 0.140 & 0.180 & 0.240 & 0.310 \\
\hline SNL governance score & 17 & 0.350 & 0.490 & 0.000 & 0.000 & 0.000 & 1.000 & 1.000 \\
\hline Log of firm size & 17 & 14.430 & 1.480 & 11.660 & 13.380 & 14.570 & 15.360 & 16.530 \\
\hline Tobin's Q & 17 & 1.550 & 0.300 & 1.030 & 1.380 & 1.540 & 1.660 & 2.240 \\
\hline Cash to assets & 17 & 0.010 & 0.010 & 0.000 & 0.000 & 0.000 & 0.020 & 0.050 \\
\hline Cumulative total return 2007-2009 & 14 & -0.580 & 0.140 & -0.820 & -0.700 & -0.590 & -0.510 & -0.270 \\
\hline \multicolumn{9}{|l|}{ Retail } \\
\hline Change in leverage & 27 & -0.030 & 0.040 & -0.090 & -0.070 & -0.030 & -0.010 & 0.020 \\
\hline Change in debt due in $2-3$ years & 26 & -0.120 & 0.310 & -0.920 & -0.180 & -0.050 & 0.080 & 0.240 \\
\hline Market leverage & 27 & 0.370 & 0.140 & 0.160 & 0.270 & 0.370 & 0.450 & 0.590 \\
\hline Share of debt due in $2-3$ years & 26 & 0.170 & 0.130 & 0.000 & 0.060 & 0.160 & 0.300 & 0.350 \\
\hline SNL governance score & 28 & 0.360 & 0.620 & 0.000 & 0.000 & 0.000 & 1.000 & 2.000 \\
\hline Log of firm size & 28 & 14.460 & 1.280 & 12.320 & 13.730 & 14.500 & 15.200 & 16.910 \\
\hline Tobin's Q & 27 & 1.670 & 0.400 & 1.160 & 1.380 & 1.630 & 1.970 & 2.460 \\
\hline Cash to assets & 28 & 0.020 & 0.030 & 0.000 & 0.000 & 0.010 & 0.020 & 0.050 \\
\hline Cumulative total return 2007-2009 & 24 & -0.620 & 0.250 & -0.930 & -0.860 & -0.620 & -0.460 & -0.220 \\
\hline \multicolumn{9}{|l|}{ Specialty } \\
\hline Change in leverage & 10 & 0.010 & 0.100 & -0.130 & -0.070 & 0.000 & 0.070 & 0.200 \\
\hline Change in debt due in $2-3$ years & 8 & 0.050 & 0.260 & -0.480 & 0.010 & 0.080 & 0.150 & 0.430 \\
\hline Market leverage & 11 & 0.350 & 0.200 & 0.000 & 0.260 & 0.360 & 0.450 & 0.740 \\
\hline Share of debt due in $2-3$ years & 9 & 0.330 & 0.240 & 0.040 & 0.140 & 0.270 & 0.550 & 0.730 \\
\hline SNL governance score & 14 & 0.290 & 0.610 & 0.000 & 0.000 & 0.000 & 0.000 & 2.000 \\
\hline Log of firm size & 11 & 13.850 & 1.720 & 9.130 & 13.690 & 14.270 & 14.350 & 16.230 \\
\hline Tobin's Q & 11 & 1.500 & 0.310 & 1.100 & 1.320 & 1.500 & 1.630 & 2.000 \\
\hline Cash to assets & 11 & 0.030 & 0.030 & 0.000 & 0.010 & 0.010 & 0.050 & 0.090 \\
\hline Cumulative total return 2007-2009 & 12 & -0.410 & 0.310 & -0.880 & -0.660 & -0.370 & -0.210 & 0.070 \\
\hline
\end{tabular}

Table A.2

The table presents the descriptive statistics for the US sample firms by property sector. Variables are defined as in Table 1. 


\section{B Descriptive statistics by property type for the European firms}

\begin{tabular}{|c|c|c|c|c|c|c|c|c|}
\hline Variable & $\mathrm{N}$ & Mean & $\mathrm{SD}$ & P5 & P25 & Median & P75 & P95 \\
\hline \multicolumn{9}{|l|}{ Diversified } \\
\hline Change in leverage & 24 & -0.020 & 0.070 & -0.100 & -0.070 & -0.020 & 0.000 & 0.090 \\
\hline Change in debt due in $1-5$ years & 18 & 0.030 & 0.150 & -0.180 & -0.010 & 0.010 & 0.050 & 0.530 \\
\hline Market leverage & 27 & 0.340 & 0.230 & 0.000 & 0.130 & 0.330 & 0.470 & 0.780 \\
\hline Share of debt due in $1-5$ years & 20 & 0.390 & 0.270 & 0.000 & 0.230 & 0.300 & 0.550 & 0.910 \\
\hline SNL governance score & 32 & 0.590 & 0.500 & 0.000 & 0.000 & 1.000 & 1.000 & 1.000 \\
\hline Log of firm size & 27 & 13.910 & 1.570 & 11.020 & 12.660 & 13.880 & 14.790 & 16.420 \\
\hline Tobin's Q & 27 & 1.130 & 0.370 & 0.750 & 0.960 & 1.080 & 1.180 & 1.940 \\
\hline Cash to assets & 27 & 0.050 & 0.060 & 0.000 & 0.010 & 0.020 & 0.070 & 0.170 \\
\hline Cumulative total return 2007-2009 & 30 & -0.540 & 0.220 & -0.840 & -0.710 & -0.580 & -0.370 & -0.180 \\
\hline \multicolumn{9}{|l|}{ Health care } \\
\hline Change in leverage & 2 & 0.000 & 0.000 & 0.000 & 0.000 & 0.000 & 0.000 & 0.000 \\
\hline Change in debt due in $1-5$ years & 2 & -0.130 & 0.180 & -0.260 & -0.260 & -0.130 & 0.000 & 0.000 \\
\hline Market leverage & 2 & 0.320 & 0.330 & 0.090 & 0.090 & 0.320 & 0.550 & 0.550 \\
\hline Share of debt due in $1-5$ years & 2 & 0.350 & 0.500 & 0.000 & 0.000 & 0.350 & 0.700 & 0.700 \\
\hline SNL governance score & 2 & 0.000 & 0.000 & 0.000 & 0.000 & 0.000 & 0.000 & 0.000 \\
\hline Log of firm size & 2 & 12.480 & 0.320 & 12.260 & 12.260 & 12.480 & 12.700 & 12.700 \\
\hline Tobin's Q & 2 & 1.370 & 0.400 & 1.100 & 1.100 & 1.370 & 1.650 & 1.650 \\
\hline Cash to assets & 2 & 0.040 & 0.030 & 0.020 & 0.020 & 0.040 & 0.060 & 0.060 \\
\hline Cumulative total return 2007-2009 & 2 & -0.690 & 0.250 & -0.870 & -0.870 & -0.690 & -0.510 & -0.510 \\
\hline \multicolumn{9}{|l|}{ Office } \\
\hline Change in leverage & 14 & -0.010 & 0.070 & -0.140 & -0.050 & -0.030 & 0.010 & 0.180 \\
\hline Change in debt due in $1-5$ years & 13 & 0.090 & 0.160 & -0.100 & 0.000 & 0.040 & 0.210 & 0.410 \\
\hline Market leverage & 17 & 0.380 & 0.160 & 0.090 & 0.290 & 0.400 & 0.430 & 0.830 \\
\hline Share of debt due in $1-5$ years & 16 & 0.440 & 0.350 & 0.000 & 0.230 & 0.380 & 0.650 & 1.070 \\
\hline SNL governance score & 19 & 0.740 & 0.450 & 0.000 & 0.000 & 1.000 & 1.000 & 1.000 \\
\hline Log of firm size & 17 & 13.980 & 0.930 & 12.000 & 13.320 & 13.920 & 14.600 & 15.670 \\
\hline Tobin's Q & 17 & 1.130 & 0.220 & 0.550 & 1.050 & 1.130 & 1.190 & 1.680 \\
\hline Cash to assets & 17 & 0.020 & 0.020 & 0.000 & 0.000 & 0.010 & 0.020 & 0.090 \\
\hline Cumulative total return 2007-2009 & 19 & -0.560 & 0.250 & -0.970 & -0.690 & -0.570 & -0.320 & -0.190 \\
\hline
\end{tabular}

Table B.1

The table presents the descriptive statistics for the European sample firms by property sector. Variables are defined as in Table 1. 


\begin{tabular}{|c|c|c|c|c|c|c|c|c|}
\hline Variable & $\mathrm{N}$ & Mean & $\mathrm{SD}$ & P5 & P25 & Median & P75 & P95 \\
\hline \multicolumn{9}{|l|}{ Residential } \\
\hline Change in leverage & 0 & $\mathrm{n} / \mathrm{a}$ & $\mathrm{n} / \mathrm{a}$ & $\mathrm{n} / \mathrm{a}$ & $\mathrm{n} / \mathrm{a}$ & $\mathrm{n} / \mathrm{a}$ & $\mathrm{n} / \mathrm{a}$ & $\mathrm{n} / \mathrm{a}$ \\
\hline Change in debt due in $1-5$ years & 0 & $\mathrm{n} / \mathrm{a}$ & $\mathrm{n} / \mathrm{a}$ & $\mathrm{n} / \mathrm{a}$ & $\mathrm{n} / \mathrm{a}$ & $\mathrm{n} / \mathrm{a}$ & $\mathrm{n} / \mathrm{a}$ & $\mathrm{n} / \mathrm{a}$ \\
\hline Market leverage & 1 & 0.520 & $\mathrm{n} / \mathrm{a}$ & 0.520 & 0.520 & 0.520 & 0.520 & 0.520 \\
\hline Share of debt due in $1-5$ years & 1 & 0.040 & $\mathrm{n} / \mathrm{a}$ & 0.040 & 0.040 & 0.040 & 0.040 & 0.040 \\
\hline SNL governance score & 2 & 0.500 & 0.710 & 0.000 & 0.000 & 0.500 & 1.000 & 1.000 \\
\hline Log of firm size & 1 & 14.990 & $\mathrm{n} / \mathrm{a}$ & 14.990 & 14.990 & 14.990 & 14.990 & 14.990 \\
\hline Tobin's Q & 1 & 1.220 & $\mathrm{n} / \mathrm{a}$ & 1.220 & 1.220 & 1.220 & 1.220 & 1.220 \\
\hline Cash to assets & 1 & 0.020 & $\mathrm{n} / \mathrm{a}$ & 0.020 & 0.020 & 0.020 & 0.020 & 0.020 \\
\hline Cumulative total return 2007-2009 & 2 & -0.440 & 0.390 & -0.720 & -0.720 & -0.440 & -0.170 & -0.170 \\
\hline \multicolumn{9}{|l|}{ Retail } \\
\hline Change in leverage & 11 & -0.030 & 0.070 & -0.110 & -0.070 & -0.040 & 0.020 & 0.150 \\
\hline Change in debt due in $1-5$ years & 8 & -0.010 & 0.160 & -0.340 & -0.070 & 0.030 & 0.090 & 0.170 \\
\hline Market leverage & 11 & 0.320 & 0.070 & 0.150 & 0.270 & 0.330 & 0.370 & 0.400 \\
\hline Share of debt due in $1-5$ years & 8 & 0.420 & 0.270 & 0.070 & 0.250 & 0.410 & 0.480 & 0.960 \\
\hline SNL governance score & 11 & 0.450 & 0.520 & 0.000 & 0.000 & 0.000 & 1.000 & 1.000 \\
\hline Log of firm size & 11 & 14.490 & 1.500 & 12.050 & 13.170 & 14.450 & 15.770 & 16.190 \\
\hline Tobin's Q & 11 & 1.180 & 0.210 & 1.000 & 1.040 & 1.140 & 1.240 & 1.670 \\
\hline Cash to assets & 10 & 0.020 & 0.020 & 0.000 & 0.000 & 0.010 & 0.040 & 0.080 \\
\hline Cumulative total return 2007-2009 & 9 & -0.590 & 0.210 & -0.850 & -0.740 & -0.680 & -0.420 & -0.210 \\
\hline \multicolumn{9}{|l|}{ Specialty } \\
\hline Change in leverage & 1 & -0.070 & $\mathrm{n} / \mathrm{a}$ & -0.070 & -0.070 & -0.070 & -0.070 & -0.070 \\
\hline Change in debt due in $1-5$ years & 2 & 0.190 & 0.220 & 0.030 & 0.030 & 0.190 & 0.340 & 0.340 \\
\hline Market leverage & 1 & 0.320 & $\mathrm{n} / \mathrm{a}$ & 0.320 & 0.320 & 0.320 & 0.320 & 0.320 \\
\hline Share of debt due in $1-5$ years & 2 & 0.890 & 0.020 & 0.880 & 0.880 & 0.890 & 0.900 & 0.900 \\
\hline SNL governance score & 2 & 0.500 & 0.710 & 0.000 & 0.000 & 0.500 & 1.000 & 1.000 \\
\hline Log of firm size & 2 & 13.210 & 0.050 & 13.170 & 13.170 & 13.210 & 13.250 & 13.250 \\
\hline Tobin's Q & 1 & 1.260 & $\mathrm{n} / \mathrm{a}$ & 1.260 & 1.260 & 1.260 & 1.260 & 1.260 \\
\hline Cash to assets & 2 & 0.020 & 0.010 & 0.020 & 0.020 & 0.020 & 0.030 & 0.030 \\
\hline Cumulative total return 2007-2009 & 1 & -0.710 & $\mathrm{n} / \mathrm{a}$ & -0.710 & -0.710 & -0.710 & -0.710 & -0.710 \\
\hline
\end{tabular}

Table B.2

The table presents the descriptive statistics for the European sample firms by property sector. Variables are defined as in Table 1. 


\section{Quintile tables}

\section{C.1 Median capital structure choices 2006 sorted by cumulative total return quintiles 2007-2009}

\begin{tabular}{lccccccc}
\hline \hline US firms - Quintile & 1 & 2 & 3 & 4 & 5 & Difference & $\left(\chi^{2}\right)$ \\
\hline Cumulative total return 2007-2009 & -0.883 & -0.753 & -0.618 & -0.470 & -0.210 & 0.673 & $\left(45.00^{* * *}\right)$ \\
Market leverage & 0.463 & 0.427 & 0.341 & 0.354 & 0.342 & -0.120 & $\left(9.058^{* * *}\right)$ \\
Share of debt due in 2-3 years & 0.223 & 0.175 & 0.147 & 0.164 & 0.074 & -0.149 & $(0.533)$ \\
Change in leverage & -0.003 & -0.026 & -0.040 & -0.029 & -0.035 & -0.032 & $\left(3.064^{*}\right)$ \\
Change in debt due in 2-3 years & 0.047 & -0.016 & -0.021 & -0.064 & 0.002 & -0.045 & $(0.533)$ \\
& & & & & & & \\
\hline European firms - Quintile & 1 & 2 & 3 & 4 & 5 & Difference & $\left(\chi^{2}\right)$ \\
\hline Cumulative total return 2007-2009 & -0.836 & -0.696 & -0.579 & -0.408 & -0.220 & 0.617 & $\left(25.000^{* * *}\right)$ \\
Market leverage & 0.396 & 0.470 & 0.301 & 0.268 & 0.419 & 0.023 & $(0.029)$ \\
Share of debt due in 1-5 years & 0.413 & 0.417 & 0.252 & 0.313 & 0.457 & 0.043 & $(0.476)$ \\
Change in leverage & -0.012 & -0.075 & -0.028 & -0.018 & 0.002 & 0.015 & $(1.000)$ \\
Change in debt due in 1-5 years & 0.000 & 0.011 & 0.006 & 0.021 & 0.034 & 0.034 & $(1.759)$ \\
\hline \hline
\end{tabular}

\section{Table C.1}

The table presents the capital structure choices of the US and European equity REITs in our sample in 2006 by quintiles of the cumulative total return 2007-2009. All variables are defined as in Table 1 . The Table also shows the spread (Difference) between the median variable values across the 5th (highest) and 1st (lowest) leverage ratio quintile alongside the corresponding $\chi^{2}$-statistic from a two-group median-comparison test. Significance is indicated as follows: ${ }^{*} p<0.1,{ }^{* *} p<0.05,{ }^{* * *} p<0.01$. 


\section{C.2 Firm characteristics sorted by changes in leverage and debt maturity in 2006 for US firms}

\begin{tabular}{lccccccc}
\hline \hline Sorted by change in leverage & 1 & 2 & 3 & 4 & 5 & Difference & (t-stat) \\
\hline Change in leverage & -0.102 & -0.054 & -0.025 & 0.001 & 0.076 & $0.178^{* * *}$ & $(14.04)$ \\
Change in debt due in 2-3 years & -0.019 & -0.053 & 0.043 & -0.066 & 0.028 & 0.046 & $(0.69)$ \\
Market leverage & 0.386 & 0.389 & 0.342 & 0.357 & 0.482 & $0.0967^{* *}$ & $(2.71)$ \\
Share of debt due in 2-3 years & 0.198 & 0.172 & 0.203 & 0.219 & 0.224 & 0.026 & $(0.42)$ \\
SNL governance score & 0.346 & 0.120 & 0.520 & 0.440 & 0.160 & -0.186 & $(-1.53)$ \\
Log of firm size & 14.447 & 14.852 & 14.143 & 13.589 & 14.064 & -0.383 & $(-1.15)$ \\
Tobin's Q & 1.548 & 1.614 & 1.608 & 1.656 & 1.268 & $-0.281^{* *}$ & $(-3.34)$ \\
Cash to assets & 0.042 & 0.025 & 0.028 & 0.036 & 0.016 & -0.026 & $(-1.55)$ \\
Cumulative total return 2007-2009 & -0.631 & -0.581 & -0.472 & -0.555 & -0.740 & -0.110 & $(-1.52)$ \\
& & & & & & & \\
\hline Sorted by change in maturity & 1 & 2 & 3 & 4 & 5 & Difference & $($ t-stat) \\
\hline Change in debt due in 2-3 years & -0.335 & -0.092 & -0.010 & 0.080 & 0.269 & $0.604^{* * *}$ & $(9.39)$ \\
Change in leverage & -0.052 & -0.006 & -0.017 & -0.030 & -0.028 & 0.024 & $(1.41)$ \\
Market leverage & 0.394 & 0.378 & 0.398 & 0.430 & 0.384 & -0.010 & $(-0.20)$ \\
Share of debt due in 2-3 years & 0.087 & 0.121 & 0.146 & 0.278 & 0.385 & $0.298^{* * *}$ & $(7.34)$ \\
SNL governance score & 0.300 & 0.350 & 0.350 & 0.350 & 0.368 & 0.068 & $(0.40)$ \\
Log of firm size & 13.671 & 14.229 & 14.320 & 14.631 & 13.951 & 0.280 & $(0.60)$ \\
Tobin's Q & 1.501 & 1.526 & 1.590 & 1.462 & 1.491 & -0.010 & $(-0.07)$ \\
Cash to assets & 0.030 & 0.040 & 0.051 & 0.021 & 0.018 & -0.012 & $(-1.18)$ \\
Cumulative total return 2007-2009 & -0.532 & -0.686 & -0.531 & -0.706 & -0.663 & -0.130 & $(-1.39)$ \\
\hline \hline
\end{tabular}

Table C.2

The table presents the firm characteristics and capital structure variables of the US equity REITs in our sample in 2006 by quintiles of the changes in leverage (top panel) and debt maturity (bottom panel), respectively. All variables are defined as in Table 1. The Table also shows the spread (Difference) between the mean variable values across the 5th (highest) and 1st (lowest) leverage ratio quintile alongside the corresponding t-statistic from a two-group mean-comparison test. Significance is indicated as follows: $*$ $p<0.1,{ }^{* *} p<0.05$, *** $p<0.01$. 


\section{C.3 Firm characteristics sorted by changes in leverage and debt maturity in 2006 for European firms}

\begin{tabular}{lccccccc}
\hline \hline Sorted by change in leverage & 1 & 2 & 3 & 4 & 5 & Difference & (t-stat) \\
\hline Change in leverage & -0.093 & -0.057 & -0.025 & -0.002 & 0.088 & $0.181^{* * *}$ & $(7.83)$ \\
Change in debt due in 1-5 years & 0.003 & 0.037 & 0.062 & 0.025 & 0.056 & 0.053 & $(0.56)$ \\
Market leverage & 0.387 & 0.397 & 0.328 & 0.224 & 0.403 & 0.016 & $(0.22)$ \\
Share of debt due in 1-5 years & 0.461 & 0.491 & 0.493 & 0.371 & 0.287 & -0.174 & $(-1.24)$ \\
SNL governance score & 0.364 & 0.500 & 0.636 & 0.500 & 0.900 & $0.536^{* *}$ & $(2.88)$ \\
Log of firm size & 15.334 & 14.426 & 13.966 & 13.446 & 12.981 & $-2.353^{* * *}$ & $(-4.50)$ \\
Tobin's Q & 1.188 & 1.212 & 1.137 & 1.196 & 1.038 & -0.150 & $(-1.42)$ \\
Cash to assets & 0.021 & 0.036 & 0.027 & 0.034 & 0.037 & 0.016 & $(0.84)$ \\
Cumulative total return 2007-2009 & -0.696 & -0.627 & -0.545 & -0.541 & -0.540 & 0.157 & $(1.75)$ \\
& & & & & & & \\
\hline Sorted by change in maturity & 1 & 2 & 3 & 4 & 5 & Difference & $($ t-stat $)$ \\
\hline Change in debt due in 1-5 years & -0.153 & -0.016 & 0.023 & 0.099 & 0.293 & $0.446^{* * *}$ & $(8.48)$ \\
Change in leverage & -0.016 & -0.045 & 0.003 & -0.043 & -0.007 & 0.009 & $(0.18)$ \\
Market leverage & 0.339 & 0.335 & 0.322 & 0.354 & 0.425 & 0.086 & $(1.13)$ \\
Share of debt due in 1-5 years & 0.348 & 0.281 & 0.472 & 0.423 & 0.735 & $0.387^{* *}$ & $(3.38)$ \\
SNL governance score & 0.667 & 0.500 & 0.714 & 0.444 & 0.875 & 0.208 & $(0.98)$ \\
Log of firm size & 13.977 & 14.224 & 13.090 & 14.981 & 13.574 & -0.403 & $(-0.73)$ \\
Tobin's Q & 1.313 & 1.200 & 1.207 & 1.064 & 1.024 & -0.289 & $(-1.36)$ \\
Cash to assets & 0.034 & 0.019 & 0.038 & 0.020 & 0.054 & 0.020 & $(0.66)$ \\
Cumulative total return 2007-2009 & -0.624 & -0.610 & -0.566 & -0.627 & -0.599 & 0.025 & $(0.20)$ \\
\hline \hline
\end{tabular}

\section{Table C.3}

The table presents the firm characteristics and capital structure variables of the European equity REITs in our sample in 2006 by quintiles of the changes in leverage (top panel) and debt maturity (bottom panel), respectively. All variables are defined as in Table 1. The Table also shows the spread (Difference) between the mean variable values across the 5th (highest) and 1st (lowest) leverage ratio quintile alongside the corresponding t-statistic from a two-group mean-comparison test. Significance is indicated as follows: $*$ $p<0.1, * * p<0.05$, *** $p<0.01$. 


\section{Descriptive statistics for regression sample in Table 5}

\begin{tabular}{|c|c|c|c|}
\hline Variable & $\mathrm{N}$ & Mean & $\mathrm{SD}$ \\
\hline \multicolumn{4}{|l|}{ Column 1} \\
\hline Cumulative total return 2007-2009 & 106 & -0.600 & 0.260 \\
\hline Market leverage & 106 & 0.380 & 0.160 \\
\hline Change in leverage & 106 & -0.030 & 0.060 \\
\hline Log of firm size & 106 & 14.230 & 1.500 \\
\hline Tobin's Q & 106 & 1.580 & 0.470 \\
\hline Cash to assets & 106 & 0.030 & 0.060 \\
\hline \multicolumn{4}{|l|}{ Column 2} \\
\hline Cumulative total return 2007-2009 & 81 & -0.620 & 0.250 \\
\hline Share of debt due in $2-3$ years & 81 & -0.020 & 0.230 \\
\hline Log of firm size & 81 & 14.210 & 1.360 \\
\hline Tobin's Q & 81 & 1.550 & 0.390 \\
\hline Cash to assets & 81 & 0.040 & 0.060 \\
\hline \multicolumn{4}{|l|}{ Column 3} \\
\hline Cumulative total return 2007-2009 & 47 & -0.590 & 0.210 \\
\hline Market leverage & 47 & 0.370 & 0.170 \\
\hline Change in leverage & 47 & -0.020 & 0.070 \\
\hline Log of firm size & 47 & 14.120 & 1.370 \\
\hline Tobin's Q & 47 & 1.170 & 0.330 \\
\hline Cash to assets & 47 & 0.030 & 0.040 \\
\hline \multicolumn{4}{|l|}{ Column 4} \\
\hline Cumulative total return 2007-2009 & 40 & -0.600 & 0.200 \\
\hline Chenge in debt due in $1-5$ years & 40 & 0.030 & 0.160 \\
\hline Log of firm size & 40 & 14.010 & 1.420 \\
\hline Tobin's Q & 40 & 1.170 & 0.350 \\
\hline Cash to assets & 40 & 0.030 & 0.050 \\
\hline
\end{tabular}

Table D.1

The table presents the descriptive statistics for the conditional regression sample in the results shown in Table 5. 


\section{E Descriptive statistics for regression sample in Tables 6 and 7}

\begin{tabular}{|c|c|c|c|}
\hline Variable & $\mathrm{N}$ & Mean & $\mathrm{SD}$ \\
\hline \multicolumn{4}{|l|}{ Column 1} \\
\hline Reduction in leverage & 126 & 0.330 & 0.470 \\
\hline High leverage $*$ Strong governance & 126 & 0.370 & 0.480 \\
\hline Market leverage & 126 & 0.410 & 0.160 \\
\hline SNL governance score & 126 & 0.320 & 0.500 \\
\hline Log of firm size & 126 & 14.060 & 1.500 \\
\hline Tobin's Q & 126 & 1.400 & 0.290 \\
\hline Cash to assets & 126 & 0.030 & 0.050 \\
\hline \multicolumn{4}{|l|}{ Column 2} \\
\hline Extension of maturity & 90 & 0.390 & 0.490 \\
\hline Short maturity $*$ Strong governance & 90 & 0.440 & 0.500 \\
\hline Share of debt due in $2-3$ years & 90 & 0.220 & 0.170 \\
\hline SNL governance score & 90 & 0.340 & 0.500 \\
\hline Log of firm size & 90 & 14.020 & 1.380 \\
\hline Tobin's Q & 90 & 1.370 & 0.280 \\
\hline Cash to assets & 90 & 0.030 & 0.050 \\
\hline \multicolumn{4}{|l|}{ Column 3} \\
\hline Reduction in leverage & 48 & 0.350 & 0.480 \\
\hline High leverage $*$ Strong governance & 48 & 0.200 & 0.400 \\
\hline Market leverage & 48 & 0.370 & 0.190 \\
\hline SNL governance score & 48 & 0.590 & 0.500 \\
\hline Log of firm size & 48 & 13.810 & 1.440 \\
\hline Tobin's Q & 48 & 1.110 & 0.250 \\
\hline Cash to assets & 48 & 0.040 & 0.060 \\
\hline \multicolumn{4}{|l|}{ Column 4} \\
\hline Extension of maturity & 41 & 0.260 & 0.450 \\
\hline Short maturity $*$ Strong governance & 42 & 0.310 & 0.470 \\
\hline Share of debt due in $1-5$ years & 41 & 0.400 & 0.270 \\
\hline SNL governance score & 41 & 0.620 & 0.490 \\
\hline Log of firm size & 41 & 13.900 & 1.480 \\
\hline Tobin's Q & 41 & 1.090 & 0.260 \\
\hline Cash to assets & 41 & 0.040 & 0.060 \\
\hline
\end{tabular}

Table E.1

The table presents the descriptive statistics for the conditional regression sample in the results shown in Tables 6 and 7. 


\section{F The role of target leverage}

\begin{tabular}{lcc}
\hline & $(1)$ & $(2)$ \\
Dependent variable: Cumulative total return 2007-2009 & US & Europe \\
\hline & & \\
Change in leverage & $-0.800^{* *}$ & $1.297^{* *}$ \\
& $(-2.10)$ & $(2.11)$ \\
Deviation from target leverage & $-0.442^{* *}$ & -0.170 \\
& $(-2.18)$ & $(-0.76)$ \\
Log of firm size & $-0.062^{* * *}$ & 0.002 \\
& $(-3.54)$ & $(0.06)$ \\
Tobin's Q & 0.034 & $0.200^{* * *}$ \\
& $(0.68)$ & $(2.86)$ \\
Cash to assets & -0.162 & -0.465 \\
& $(-0.44)$ & $(-0.61)$ \\
Constant & $0.515^{*}$ & $-0.968^{*}$ \\
& $(1.78)$ & $(-2.01)$ \\
R-squared & & \\
Sector effects & 106 & 47 \\
\hline
\end{tabular}

Table F.1

The table presents the regression results corresponding to the main results in Table 5 with deviations from target leverage as an alternative control variable to the overall level of leverage. Target leverage is estimated in a first stage as a function of the firm characteristics in considered our study. 